\title{
Genç Nüfusun Yaşlı Ayrımcılığı Tutum Düzeyinin Sosyodemografik Değişkenler Açısından İncelenmesi: Manisa Örneği
}

Öz

Birleşmiş Milletlerin verilerine göre 2020 yllında dünya genelinde 65 yaş ve üstü 727 milyon kişi bulunmaktadır. 2050 yılına kadar dünyadaki yaşlı sayısının iki katından daha fazla artacağı ve 1,5 milyarın üzerine çıkacağı tahmin edilmektedir. Bu tahmin yaşlılara yönelik yapılması gereken farklı çalışmaları gündeme getirmektedir. Bu çalışmanın temel amacı Manisa ili örnekleminde genç nüfusun yaşlı ayrımcılığına yönelik tutum düzeyinin belirlenmesidir. Tarama modeli kullanılarak gerçekleştirilen bu araştırmada, evren içindeki hedef örnekleme ulaşılabilmek amacıyla kolayda örnekleme yönetimi tercih edilmiş ve toplam 601 katılımcıya ulaşılmıştır. Veriler 14 Kasım 2020 - 04 Mart 2021 tarihleri arasında toplanmıştır. Araştırmada Vefikuluçay Yılmaz ve Terzioğlu (2011) tarafından geliştirilen "Yaşlı Ayrımcılığı Tutum Ölçeği (YATÖ)” veri toplama aracı olarak kullanılmıştır. Ölçek puanlarının cinsiyet, medeni durum ve ailede yaşlı birey varlığı değişkenlerine göre karşılaştırılmasında bağımsız örneklem t testinden; yaş grupları, yerleşim yeri, istihdam, aylık gelir, aile tipi, herhangi bir yaşlı ile bir araya gelme sıklığı, yaşlı bir birey ile aynı evde yaşama tercihi değişkenlerine göre karşılaştırılmasında ise ANOVA testinden yararlanılmıştır. Araştırma sonuçlarına göre katılımcıların YATÖ toplam puan ortalamaları 85,06₫8,49 olarak tespit edilmiştir. Bu sonuç Türkiye'de özellikle üniversite öğrencileri arasında gerçekleştirilen araştırma sonuçlarına benzerdir. Bu benzerlik Türkiye'deki geleneksel, ataerkil ve alturistik toplumsal yapının örneklemde yer alan gençler üzerinde hâlâ etkin şekilde varlığını sürdürdüğünün bir göstergesi olarak değerlendirilebilir.

Anahtar Kelimeler: Genç Nüfus, Kuşaklararası, Manisa, Türkiye, Yaşlı Ayrımcılığı.

* Dr. Öğr. Üyesi, Recep Tayyip Erdoğan Üniversitesi, Sağlık Bilimleri Fakültesi, Sosyal Hizmet Bölümü, bekir.guzel@ erdogan.edu.tr, ORCID: 0000-0002-0795-0768. 


\begin{abstract}
According to United Nations data, there were 727 million people aged 65 and over worldwide in 2020. It is estimated that by 2050, this number will more than double, reaching an excess of 1.5 billion. This figure indicates the need for studies to be conducted with the elderly. This study follows a survey model in its aim to gauge young people's attitudes toward ageism in Turkey's province of Manisa. Using convenience sampling, we selected 601 participants to make up the study's sample. We collected data between November 14, 2020 and March 04, 2021 using the Ageism Attitude Scale (AAS) developed by Vefikuluçay Yılmaz and Terzioğlu (2011). We conducted an independent sample t-test to compare the scale scores by gender, marital status, and the presence of an elderly member in the family. We then carried out an ANOVA to compare age groups, places of residence, employment, monthly income, family type, frequency of meeting an elderly person, and preference of living in the same house with an elderly individual. The findings revealed that participants' total average AAS scores were $85.06 \pm 8$.49. This specific finding bore resemblance to previous studies carried out with university students in Turkey. The results, therefore, indicate that a traditional, patriarchal, and altruistic social structure prevails among the young people participating in our study.
\end{abstract}

Keywords: Ageism, Intergenerational, Manisa, Turkey, Young People.

\title{
Giriş
}

José Saramago (2013) “Ölüm Bir Varmış Bir Yokmuş” adlı romanına "İnsan olmanın ne demek olduğunu her geçen gün daha az bileceğiz.” diyerek başlamaktadır. Romanın bir bölümünde adı bilinmeyen bir ülkede öl(e)meyen insanların yaşadıklarına tanık oluruz. ìlk başlarda insanlar bu durum karşısında sevinç çı̆̆lıkları atarlar; ama yaş almaya da devam ederler. Bir süre sonra iyice yaşlanırlar ve gelecekte onları bekleyen sonsuz bir yaşlılık hissine kapılırlar. Yıllar geçer; ama ölüm isteseler de bir türlü kapılarını çalmaz...

Bugün Saramago'nun tasvir ettiği gibi distopik bir durum içinde bulunmasak da tüm dünyada yaşlı nüfus giderek artmaktadır. Birleşmiş Milletlerin (BM) verilerine göre 2020 yılında dünya genelinde 65 yaş ve üstü 727 milyon kişi bulunmaktadır. 2050 yılına kadar dünyadaki yaşlı sayısının iki katından daha fazla artacağı ve 1,5 milyarın üzerine çıkacağı tahmin edilmektedir. Benzer bir durum Türkiye özelinde de söz konusudur. Türkiye İstatistik Kurumu (TÜIK) verilerine göre Türkiye'deki yaşlı nüfus 2015-2020 yılları arasında \%22,5 oranında artarak 7 milyon 953 bin 555 kişiye ulaşmıştır. Aynı dönemde Türkiye'deki yaşlı nüfusun toplam nüfus içindeki oranı da \%8,2'den \%9,5'e yükselmiştir. Bu oranın her geçen yıl artacağı ve 2080 yılında Türkiye'deki yaşlı nüfusun toplam nüfus içindeki oranının \%25,6 olacağı öngörülmektedir (TÜìK, 2020a). Yaşlı nüfusun toplam nüfus içindeki artış eğilimine rağmen başta Türkiye olmak üzere pek çok ülkede 18-24 yaş arası genç nüfusun giderek azaldığı görülmektedir. BM (2015) genç nüfus projeksiyonlarına göre; önümüzdeki yarım asırlık sürede Afrika ülkeleri dışındaki ülkelerin pek çoğunda genç nüfus ya sabit kalacak ya da azalacaktır. Örneğin; Latin Amerika ve Karayipler, Avrupa, Kuzey Amerika ve Okyanusya ülkelerinde genç nüfus artışı sabitlenmiş olup, önümüz- 
deki yıllarda çok az bir değişimin olacağı tahmin edilmektedir (BM, 2015). Benzer şekilde TÜiK (2020b) nüfus projeksiyonlarında 2023 yılında \%14,8 olacağı tahmin edilen genç nüfusun toplam nüfus içindeki oranının 2030 yılında \%14'e; 2040 yılında \%13,4'e; 2060 yılında \%11,8'e ve 2080 yllında \%11,1'e düşeceği öngörülmektedir. Bu istatistiki veriler her iki gruba yönelik çeşitli çalışmaların yapılması zorunluluğunu ortaya çıkarmaktadır. Nitekim artan yaşlı nüfus oranıyla birlikte yaşlıların ve gençlerin karşılaşma, etkileşim içine girme ve ortak yaşam alanlarını paylaşma ihtimali de artmaktadır. Bu süreçler içinde genç nüfusun yaşlı nüfusa yönelik nasıl bir algıya (duygu ve düşünce) ve tutuma (davranış) sahip olacağını öngörmek oldukça zordur. Ancak bugünden yapılacak araştırmalar mevcut durumun tespit edilmesi ve geleceğe yönelik öngörülerde bulunulması açısından önem arz etmektedir. Bu çalışma da böyle bir düşünceden hareketle azalan genç nüfusun artan yaşlı nüfusa yönelik tutumunun belirlenmesi amacıyla gerçekleştirilmektedir. Bu çalışmanın temel amacı Manisa ili örnekleminde genç nüfusun yaşlı ayrımcılığına yönelik tutum düzeyinin belirlenmesidir.

\section{Yaşlı Ayrımcılığı}

Yaşlı ayrımcılığı kavramına değinmeden önce kısaca yaşlılık kavramına değinmekte yarar var. Yaşlılık ile ilgili çalışmalar incelendiğinde; bu kavramın geçmişten bugüne farklı şekillerde tanımlandığı görülmektedir. Dünya Sağlık Örgütü (DSÖ) (2001) yaşlı ya da yaşlılık ile ilgili tanımların ve kategorilerin evrensel olarak kullanılabilir olmadığından ve cinsiyete, kişiye, zamana, bölgeye, ülkeye ve kültüre göre farklılık gösterebileceğinden bahsetmektedir. Antik dönemde Aristoteles’in hastalığı "zamansız gelen yaşlılık”, yaşlılığı ise "doğal bir hastalık" olarak nitelendirdiği ifade edilmektedir (Çağlar, 2017). Yaşlılığı, yaşam sürecinin tıpkı çocukluk, gençlik ve yetişkinlik gibi doğal ve zorunlu bir dönemi (Kutsal, 2003) olarak tanımlayan çalışmalar olduğu gibi; yaşamın her açıdan kayba uğranılan bir dönemi olarak tanımlayan çalışmalar da bulunmaktadır (Çağlar, 2017). DSÖ (2001) tarafından yapılan çalışmalara bakıldığında; yaşlılığın yaş ile birlikte ortaya çıkan evrensel ve biyolojik değişimler süreci olarak tanımlandığı ve 65 yaşın yaşlılık çalışmalarında başlangıç süreci olarak kabul edildiği görülmektedir.

Yaşlı ayrımcılığı kavramı ilk defa 1969 yılında Amerika Ulusal Yaşlılık Enstitüsü Başkanı Robert Butler tarafından kullanılmıştır. Butler (1980) yaşlı ayrımcılığını yaşlı bireylere yönelik ırk ayrımcılığı ve cinsiyet ayrımcılığı gibi herhangi bir ayrımcılık türüne dönüşebilen ideolojik temelli bir eylem olarak tanımlamaktadır. Bond ve Cabrero (2007) ise yaşlı ayrımcılığını, insanların tıpkı deri renginden ya da cinsiyetinden dolayı olumsuz ayrımcılığa maruz kaldıkları gibi, yaşlarından dolayı sistematik olarak kötü söz ve tutumlara maruz kalmaları olarak ifade etmektedir (Kurtkapan, 2019). Bu eylem ve tutumlar, yaşlılarla aynı ortamda bulunmaktan veya iletişim kurmaktan kaçınma, onları görmezden gelme veya yok sayma ya da onlar üzerinde baskı oluşturma gibi farklı şekillerde karşımıza çıkabilmektedir. Yaşlı ayrımcılığının bazı kaynaklarda kronolojik bir kavramsallaştırmaya dayandırıldığı ve yaşlandıkça oluşan yetersizliklerin, sınırlılıkların ve olumsuz değişikliklerin yorumlanması olarak tanımlandığı 
görülmektedir (Çilingiroğlu ve Demirel 2004; Yllmaz ve Özkan 2010; akt. Zaybak ve ark., 2017). Yaşlılara yönelik ayrımcılık; toplumsal alanda yaşlıların bağımlı ve bakıma muhtaç olarak algılanması, muhatap alınmaması, sosyal hayattan dışlanması ve istismar edilmesi gibi görünümlerle ortaya çıkmaktadır (Buz, 2015). Ayrıca modern toplumda yaşlılar, yaşlanma ve yaşlılık ile ilgili bu olumsuz bakış açısı; yerel, ulusal veya küresel medyadaki pek çok yayında karşımıza çıkmakta ve insanların yaşlı ayrımcılığına yönelik tutum düzeyini şekillendirmektedir (Demez, 2012).

\section{Yaşlı Ayrımcılığı ile İlgili Çalışmalar}

Yaşlı ayrımcılığına yönelik yapılan çalışmalarda milenyum sonrası yıllarda niceliksel bir artışın yaşandığı görülmektedir (Palmore, 2001; Greenberg ve ark., 2002; Çilingiroğlu ve Demirel, 2004; Palmore ve ark., 2005; Bytheway, 2005; Iversen ve ark., 2009; Gullette, 2011; Vefikuluçay Yllmaz ve Terzioğlu, 2011; Achenbaum, 2015; Buz, 2015; Levy ve Macdonald, 2016; Nelson, 2016; Wyman ve ark., 2018; Officer ve Fuente-Núñez, 2018; Meisner, 2020). Nitekim sadece Google Scholar üzerinden yaşlı ayrımcılığı (ageism) kelimesi kullanılarak yapılan bir taramada 19502000 yılları arasında yaklaşık 12.300 çalışmaya ulaşılırken; 2000-2020 yılları arasında yaklaşık 34.600 çalışmaya ulaşılmaktadır. Bu çalışmalarda yaşlı ayrımcılığı farklı gruplar, değişkenler, faktörler veya konular ile ilişkili olarak ve çeşitli ölçekler kullanılarak ele alınmıştır. Konu Türkiye özelinde ele alındığında literatürdeki çalışmaların bazılarında (Ucun ve ark., 2015; Altay ve Aydın, 2015; Ceylan ve Öksüz, 2015; Zaybak ve ark., 2017; Boz ve ark., 2017; Kaçan ve ark., 2018; Kurtkapan, 2019; Temiz ve Öztürk, 2019) bu araştırmada da kullanılan "Yaşlı Ayrımcılığı Tutum Ölçeği (YATÖ)” kullanılmıştır. Bazı çalışmalarda (Adıbelli ve ark., 2013; Koç ve ark., 2018; Baysal ve ark., 2019; Pehlivan ve Vatansever, 2019) ise “Kogan Yaşlı Tutum Ölçeği” (KYTÖ)” kullanıldığı görülmektedir. Bu çalışmaların hepsinde katılımcıların yaşlı nüfusa yönelik nasıl bir algıya (duygu ve düşünce) ve tutuma (davranış) sahip oldukları araştırılmaktadır.

Mevcut çalışmanın ölçeği, amacı ve örneklemi literatürdeki çalışmalarla mukayese edildiğinde; Türkiye'de genç nüfusun yaşlılara yönelik algısını ve yaşlı ayrımcılığına yönelik tutumunu değerlendiren farklı çalışmaların da bulunduğu görülmüştür. Ucun ve arkadaşları (2015) tarafından Bilecik’te yapılan araştırmada gençlerin YATÖ toplam puan ortalaması 70,69 $\pm 8,72$ olarak tespit edilmiştir. Ölçekten alınabilecek en yüksek puanın 115, en düşük puanın ise 23 olduğu düşünüldüğünde; gençlerin orta düzeyde bir tutum puanına sahip olduğu anlaşılmaktadır. Temiz ve Öztürk (2019) tarafından Sivas’ta yapılan bir başka araştırmada, genç nüfusun YATÖ toplam puan ortalaması $82,48 \pm 10,5$ olarak tespit edilmiş ve olumlu düzeyde yüksek bir puan olarak rapor edilmiştir. Zaybak ve arkadaşları (2017) tarafından Ege Üniversitesi Hemşirelik Fakültesi'nde öğrenim gören öğrencilere yönelik yapılan bir araştırmada YATÖ toplam puan ortalaması 85,75£10,35 olarak belirlenmiştir. Bu araştırmada katılımcıların yaşlılara yönelik tutum puan ortalaması yüksek bulunmakla birlikte; yaş, cinsiyet, yaşlı bireylerle birlikte yaşama durumu 
ve profesyonel hayatta yaşlı bireylerle çalışmayı düşünme durumu arasında anlamlı bir fark bulunamamıştır (Zaybak ve ark., 2017).

Nevşehir'de yapılan bir araştırmada (Kurtkapan, 2019) ise gençlerinin yaşlı ayrımcılığına yönelik pozitif bir tutum içerisinde bulundukları sonucuna ulaşılmıştır. Bu çalışmada kadın katılımcıların erkek katılımcılara oranla daha pozitif tutuma sahip oldukları tespit edilmiştir. Ayrıca yaşlı bireylerle birlikte yaşayan katılımcıların, yaşlı bireylerle yaşamayan katılımcılara oranla daha pozitif bir tutum içinde oldukları anlaşılmaktadır (Kurtkapan, 2019). Yılmaz ve Özkan (2010) tarafından yaş ortalaması 20 olan bir grup üzerinde yapılan araştırmada, katılımcı-

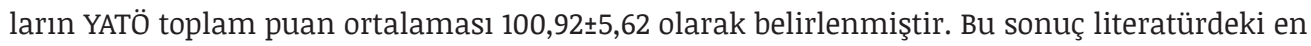
yüksek YATÖ toplam puan ortalamalarından biridir. Meslek yüksekokulunda yapılan bir başka araştırmada (Altun ve Demirel 2020), katılımcıların YATÖ toplam puan ortalaması 69,57₫8,27 olarak tespit edilmiştir. Bu puan ortalaması, ortalamanın üzerinde olmakla birlikte; diğer pek çok araştırmaya göre düşük bir puan ortalaması olarak kabul edilebilir. Araştırmada, erkek öğrencilerin kadın öğrencilere oranla yaşlı ayrımcılığına yönelik tutumlarının daha olumlu olduğu ifade edilmektedir. Öğrencilerin çekirdek ya da geniş aileye sahip olmaları onların yaşlı ayrımcılığına yönelik tutumlarını etkilememektedir. Araştırmada, öğrencilerin okudukları bölüme göre yaşlı ayrımcılığına yönelik tutumlarında anlamlı farklılıkların bulunduğu görülmekte ve özellikle Muhasebe ve Vergi Uygulamaları programına kayıtlı öğrencilerin yaşlı ayrımcılığına yönelik tutumlarının daha olumlu olduğu ifade edilmektedir (Altun ve Demirel, 2020).

Yalova'da Ceylan ve Öksüz (2015) tarafından sosyal hizmet bölümü öğrencileri üzerinde yapılan bir araştırmanın sonuç bölümünde, katılımcıların genel olarak yaşlı ayrımcılığına yönelik olumlu bir tutuma sahip oldukları ifade edilmektedir. Sosyal hizmetin doğrudan yaşlı nüfus ile birlikte çalışan bir alan ya da disiplin olduğu düşünüldüğünde; öğrencilerin olumlu bir tutuma sahip olması beklenen bir sonuç olarak değerlendirilebilir. Altun ve Demirel (2020)'in çalışmasında olduğu gibi bu araştırmada da erkek katılımcıların kadın katılımcılara oranla daha olumlu bir tutuma sahip oldukları tespit edilmiştir. Bu araştırmada cinsiyet değişkeninden bağımsız olarak yaşlılık dersi alan öğrencilerin yaşlı ayrımcılığına yönelik tutumu, bu dersi almayan öğrencilere oranla daha yüksektir. Ayrıca YATÖ toplam puanında geniş evde oturan katılımcılar ile daha küçük evlerde oturan katılımcılar arasında istatistiksel olarak anlamlı bir fark bulunmaktadır (Ceylan ve Öksüz, 2015).

Yapılan literatür taramasında, Türkiye'deki genç nüfusun yaşlı ayrımcılı̆̆ı tutum düzeyinin ortalamanın üzerinde olduğu anlaşılmaktadır. İncelemeye dâhil edilen hiçbir araştırmada genç nüfusun yaşlılara yönelik düşük düzeyde ya da olumsuz bir tutuma sahip olduğu tespit edilmemiştir. Ancak bazı çalışmalarda cinsiyete, bölüme, sınıfa, aile yapısına, yaşlı bir birey ile birlikte yaşama ve yaşlılarla ilgili ders alma durumuna göre değişen tutum düzeyleri tespit edilmiştir. Burada en dikkat çekici nokta genç nüfus ile yapılan araştırmaların genellikle üniversite öğrencileri üzerinden gerçekleştirilmiş olmasıdır. Bu nedenle incelenen araştırmaların 
çoğunda; medeni durum, çalışma durumu ve ikamet edilen yerleşim yeri gibi sosyoekonomik ve demografik değişkenler üzerinden farklı analizler yapıl(a)mamıştır. Bu araştırmanın Manisa ilinde yaşayan genç nüfusa yönelik olması; üniversite eğitimi alan/almayan, bekâr/ evli olan veya çalışan/çalışmayan pek çok gencin de araştırmaya dâhil edilmesine imkân sağlamaktadır. Bu durum, söz konusu araştırmayı aynı ölçek kullanılarak yapılmış pek çok araştırmadan ayıracak ve bu araştırmanın literatürde özgün bir yere sahip olmasına katkı sağlayacaktır.

Bu çalışmada esas olarak aşağıdaki sorulara yanıtlar aranmıştır.

(1) Manisa ilinde ikamet eden genç nüfusun yaşlı ayrımcılığı tutum düzeyi hangi seviyededir?

(2) Manisa ilinde ikamet eden genç nüfusun yaşlı ayrımcılığı tutum düzeyi ile sosyodemografik değişkenleri arasında bir ilişki var mıdır?

\section{Yöntem}

$\mathrm{Bu}$ araştırma nicel araştırma türleri arasında yer alan tarama (survey) modeli esas alınarak gerçekleştirilmiştir. Bu model araştırmacılara herhangi bir konuyla ilgili katılımcı görüşlerini tespit etme veya algı ve tutum gibi özellikleri belirleme noktasında gerekli imkânı sağlaması (Demirel, 2018) bakımından tercih edilmiştir. Nitekim tarama modeli, geçmişte ya da içinde bulunulan zamanda, var olan bir durumu olduğu haliyle tespit etmeyi amaçlayan bir araştırma modelidir (Karasar, 2020).

\section{Evren ve Örneklem}

Manisa ilinde ikamet eden genç nüfus bu araştırmanın evrenini oluşturmaktadır. Gençlik araştırmaları ile ilgili literatürde genç nüfus genel olarak 15-24 yaş arası bireyleri kapsayacak şekilde kullanılmaktadır (Ansell, 2005). Ancak bu araştırmada iki nedenden dolayı örnekleme dâhil edilecek bireylerin yaş aralığı 18-30 olarak belirlenmiştir. Bu nedenlerden ilki 18 yaş altı bireylerin veri toplama süreçlerine dâhil edilmeleri sırasında gerekli olacak farklı etik izinlerle ilgilidir. Diğer neden ise araştırmanın sadece 15-24 yaş arası bireylerle sınırlı tutulması sonucunda yeterli sayıda örnekleme ulaşılamayacağı öngörüsüdür. TÜiK (2021) verilerine göre Manisa ilinde ikamet eden 18-30 yaş arası kişi sayısı 265.586'dır. Bu araştırmada, evren içindeki hedef örnekleme ulaşılabilmek amacıyla kolayda örnekleme yönetimi kullanılmıştır. Bu yöntem olasılığa dayalı olmaması, araştırmacıya zaman ve maliyet açısından kolaylık sağlaması nedeniyle tercih edilmiştir (Stratton, 2021). Bu araştırma kapsamında toplam 601 katılımcıya ulaşılmıştır. 
Tablo 1. Katılımcıların Demografik Özelliklerine Göre Dağılımı

\begin{tabular}{|c|c|c|c|}
\hline Demografik Değişken & Gruplar & $\mathbf{n}$ & $\%$ \\
\hline \multirow{2}{*}{ Cinsiyet } & Kadın & 264 & 43,9 \\
\hline & Erkek & 337 & 56,1 \\
\hline \multirow{3}{*}{ Yaş } & 18-21 yaş & 115 & 19,1 \\
\hline & 22-25 yaş & 240 & 39,9 \\
\hline & 26-30 yaş & 246 & 40,9 \\
\hline \multirow{3}{*}{ Medeni durum } & Evli & 177 & 29,5 \\
\hline & Bekâr & 424 & 70,5 \\
\hline & İlköğretim & 55 & 9,2 \\
\hline \multirow[t]{3}{*}{ öğrenim durumu } & Lise & 244 & 40,6 \\
\hline & Üniversite & 302 & 50,2 \\
\hline & Manisa il merkezi & 187 & 31,1 \\
\hline \multirow[t]{3}{*}{ Yerleşim yeri } & İlçe & 327 & 54,4 \\
\hline & Mahalle/köy/kasaba & 87 & 14,5 \\
\hline & Kamu & 146 & 24,3 \\
\hline \multirow[t]{4}{*}{ İstihdam durumu } & Özel & 236 & 39,3 \\
\hline & Çalışmıyor & 219 & 36,4 \\
\hline & 1000TL ve altı & 47 & 7,8 \\
\hline & 1001-2500TL & 116 & 19,3 \\
\hline \multirow{5}{*}{ Aylık gelir } & 2501-3500TL & 184 & 30,6 \\
\hline & 3501-5000TL & 144 & 24,0 \\
\hline & 5001-6000TL & 48 & 8,0 \\
\hline & 6001TL ve üstü & 62 & 10,3 \\
\hline & Çekirdek aile & 471 & 78,4 \\
\hline \multirow[t]{2}{*}{ Aile tipi } & Geniş aile & 99 & 16,5 \\
\hline & Yalnız yaşıyor & 31 & 5,2 \\
\hline \multirow{2}{*}{$\begin{array}{c}\text { Ailesinde birlikte } \\
\text { yaşadığı yaşlı birey } \\
\text { var mı? }\end{array}$} & Evet & 149 & 24,8 \\
\hline & Hayır & 452 & 75,2 \\
\hline
\end{tabular}




\begin{tabular}{cccc} 
& Hiç & 32 & 5,3 \\
Yyllda bir & 109 & 18,1 \\
& Ayda bir & 141 & 23,5 \\
& Ayda birkaç kez & 114 & 19,0 \\
\cline { 2 - 4 } & Her gün & 205 & 34,1 \\
Tercih hakkı olsa yaşlı & Evet & 311 & 51,7 \\
bir birey ile aynı evde & Haysımama isteği & 96 & 16,0 \\
yaşarsız & 194 & 32,3 \\
\hline
\end{tabular}

\section{Veri Toplama Aracı}

Araştırmada iki bölümden oluşan bir veri toplama aracı kullanılmıştır. Veri toplama aracının ilk bölümünde; katılımcıların cinsiyeti, yaşı, medeni durumu, öğrenim durumu, yaşadığı yer, istihdam durumu, aylık geliri, aile tipi, ailede yaşlı bireyin varlığı, herhangi bir yaşlı ile bir araya gelme sıklığı, yaşlı bir birey ile aynı evde yaşama istekliliği gibi sorulardan oluşan sosyodemografik bilgi formu yer almaktadır.

Veri toplama aracının ikinci bölümünde Vefikuluçay Yılmaz ve Terzioğlu (2011) tarafından geliştirilerek geçerlik ve güvenirlik çalışmaları yapılan "Yaşlı Ayrımcılığı Tutum Ölçeği (YATÖ)" yer almaktadır. Ölçekte 65 yaş ve üzerindeki bireylere yönelik yaşlı ayrımcılığına ilişkin ifadelerden oluşan beşli likert tipinde (1: kesinlikle katılmıyorum, 5: tamamen katılıyorum) 23 madde ve 3 alt boyut (yaşlının yaşamını sınırlama, yaşlıya yönelik olumlu ayrımcılık, yaşlıya yönelik olumsuz ayrımcılık) yer almaktadır. Ölçeğin ortalama puanı, olumlu ifadeler içeren 9 madde $(2,4,6,7,8,9,13,20$, 23) için tamamen katılıyorsa 5 puan, kesinlikle katılmıyorsa 1 puan üzerinden hesaplanırken; olumsuz ifade içeren 14 madde $(1,3,5,10,11,12,14,15,16,17,18,19$, 21, 22) için hesaplama tamamen katılıyorsa 1 puan, kesinlikle katılmıyorsa 5 puan üzerinden hesaplanmıştır. Bu şekilde elde edilen ölçek puanının yüksekliği yaşlı ayrımcılığına ilişkin tutumun yüksek (olumlu) düzeyde; düşüklüğü ise düşük (olumsuz) düzeyde olduğunu göstermektedir. Bu çalışmada ölçeğin Cronbach Alfa güvenirlik katsayısı 0,76; alt boyutların Cronbach Alfa güvenirlik katsayıları sırasıyla 0,64, 0,78 ve 0,60 olarak hesaplanmıştır.

\section{Veri Toplama Süreci}

Araştırmada kullanılacak ölçek ile ilgili gerekli izinler alındıktan sonra veri toplama aracı olarak kullanılacak sosyodemografik bilgi formu ve ölçek soruları Google Formlar uygulamasına aktarılmıştır. Oluşturulan araştırma linki, Manisa ilinde ikamet eden genç nüfusun üye olduğu Facebook, Twitter ve Instagram gibi çeşitli sosyal medya platformlarında yaklaşık bir ay boyunca belirli aralıkla paylaşılmıştır. Ancak bir süre sonra hedeflenen katılımcı sayısına bu platformlar aracılığıyla ulaşılamayacağı anlaşılmıştır. Bunun üzerine Manisa ilinde genç nüfusa yönelik faaliyet gösteren sivil toplum kuruluşlarına, gençlik merkezlerine ve siyasi par- 
tilerin gençlik kolları temsilciliklerine ulaşılarak, gönüllülük esasına bağlı olmak şartıyla, söz konusu kurumların/kuruluşların üyeleri ve/veya yararlanıcıları tarafından doldurulması için ilgili araştırma linkinin paylaşılması talep edilmiş ve verilerin bir kısmı söz konusu kurumların/kuruluşların üyelerinden ve/veya yararlanıcılarından elde edilmiştir. Verilerin toplanması 14 Kasım 2020 - 04 Mart 2021 tarihleri arasında gerçekleştirilmiştir.

\section{Verilerin Analize Edilmesi}

Verilerin analiz edilmesinde SPSS 21.0 programı kullanılmıştır. Ölçek puanlarının normallik sınamasında çarpıklık (skewness) ve basıklık (kurtosis) katsayılarından yararlanılmıştır. Tablo 2'de yer alan çarpıklık ve basıklık değerleri incelendiğinde; ölçek ve alt boyut puanlarının normal dağılım gösterdiği tespit edilmiştir. Bilindiği üzere sürekli bir değişkenden elde edilen puanların normal dağılım özelliğinde kullanılan çarpıklık ve basıklık katsayılarının \pm 1 sınırları içinde kalması, puanların normal dağıldığının göstergesi olarak kabul edilmektedir (Büyüköztürk, 2019). Normal dağılan veriler parametrik veri analizi teknikleri kullanılarak analiz edilmiştir. Ölçek puanlarının cinsiyet, medeni durum ve ailede yaşlı birey varlığı değişkenlerine göre karşılaştırılmasında bağımsız örneklem t testinden; yaş grupları, yerleşim yeri, istihdam, aylık gelir, aile tipi, herhangi bir yaşlı ile bir araya gelme sıklığı ve yaşlı bir birey ile aynı evde yaşama tercihi değişkenlerine göre karşılaştırılmasında ise ANOVA testinden yararlanılmıştır. Ayrıca ANOVA testinde anlamlı farklılık görüldüğünde, farkın hangi gruplar arasında olduğunu belirlemek amacıyla Scheffe çoklu karşılaştırma testinden yararlanılmış ve analizlerde güven aralığı \%95 (p<0,05) olarak belirlenmiştir.

\section{Bulgular}

Katılımcıların demografik özelliklerine göre dağılımına, evren ve örneklem bölümünde yer alan Tablo 1'de yer verilmiştir. Ölçeğe verilen cevapların analizinden önce kutu grafikleri oluşturularak, veri setinde uç değerlerin olup olmadığı araştırılmış ve veri setinde dört adet uç değerin bulunduğu sonucuna ulaşılmıştır. Uç değerlere sahip olan katılımcılar veri setinden çıkarılmış ve böylece toplam 597 katılımcının verisi kullanılarak ölçeğe dair analizler gerçekleştirilmiştir.

Tablo 2. Yaşlı Ayrımcılığı Tutum Puanlarına Ait Betimsel İstatistikler

\begin{tabular}{cccccccc}
\hline Alt Boyut & $\mathbf{n}$ & Min. & Maks. & $\overline{\mathbf{X}}$ & SS & Çarpıklık & Basıklık \\
\hline $\begin{array}{c}\text { Yaşlının yaşamını } \\
\text { sinırlama }\end{array}$ & 597 & 20 & 45 & 36,27 & 4,21 & $-0,62$ & 0,83 \\
\cline { 2 - 7 } $\begin{array}{c}\text { Yaşlıya yönelik olumlu } \\
\text { ayrımcılık }\end{array}$ & 597 & 17 & 40 & 31,99 & 4,32 & $-0,47$ & 0,40 \\
\cline { 2 - 7 } $\begin{array}{c}\text { Yaşlıya yönelik } \\
\text { olumsuz ayrımcılık }\end{array}$ & 597 & 6 & 30 & 16,80 & 3,43 & 0,19 & 0,37 \\
\cline { 2 - 7 } \\
YATÖ TOPLAM PUAN
\end{tabular}


Katılımcıların, yaşlının yaşamını sınırlama faktörü tutum puanı 36,27 $\pm 4,21$; yaşlıya yönelik olumlu ayrımcılık faktörü tutum puanı 31,99₫4,32; yaşlıya yönelik olumsuz ayrımcılık faktörü tutum puanı 16,80 $\pm 3,43$ ve YATÖ toplam puanı $85,06 \pm 8,49$ olarak tespit edilmiştir. Bu araştırmada hesaplanan puanlara göre; katılımcıların yaşlının yaşamını sınırlamaya ilişkin olumlu tutuma, yaşlıya yönelik olumlu ayrımcılığa ilişkin olumlu tutuma, yaşlıya yönelik olumsuz ayrımcılığa ilişkin olumlu tutuma ve genel olarak yaşlı ayrımcılığına yönelik olumlu tutuma sahip oldukları anlaşılmaktadır.

Katılımcıların YATÖ toplam puan ortalamasının cinsiyete göre anlamlı bir farklılık $(\mathrm{p}>0,05)$ göstermediği anlaşılmaktadır. Buna karşın cinsiyete göre yaşlının yaşamını sınırlama, yaşlıya yönelik olumlu ayrımcılık ve yaşlıya yönelik olumsuz ayrımcılık faktörleri puan ortalamalarının anlamlı bir farklılık $(\mathrm{p}<0,05)$ gösterdiği belirlenmiştir. Kadın katılımcıların yaşlının yaşamını sınırlama ve yaşlıya yönelik olumsuz ayrımcılık faktörlerinin puan ortalamaları daha yüksek düzeyde olurken; erkek katılımcıların yaşlıya yönelik olumlu ayrımcılık puan ortalamalarının anlamlı olarak daha yüksek olduğu bulunmuştur.

Tablo 3. Yaşlı Ayrımcılığı Tutum Puanlarının Yaş Gruplarına Göre Karşılaştırılması

\begin{tabular}{|c|c|c|c|c|c|c|c|}
\hline Alt Boyut & Yaş & $\mathbf{n}$ & $\overline{\mathbf{x}}$ & SS & $\mathbf{F}$ & p & $\begin{array}{l}\text { Anlamlı } \\
\text { Fark }\end{array}$ \\
\hline \multirow{3}{*}{$\begin{array}{l}\text { Yaşlının yaşamını } \\
\text { sinırlama }\end{array}$} & A-18-21 yaş & 115 & 35,44 & 4,59 & \multirow{3}{*}{5,61} & \multirow{3}{*}{0,00} & $\mathrm{C}>\mathrm{A}$ \\
\hline & B-22-25 yaş & 240 & 36,01 & 4,35 & & & \\
\hline & C-26-30 yaş & 242 & 36,92 & 3,77 & & & \\
\hline \multirow{3}{*}{$\begin{array}{l}\text { Yaşlıya yönelik olumlu } \\
\text { ayrımcıllk }\end{array}$} & A-18-21 yaş & 115 & 30,20 & 4,77 & \multirow{3}{*}{17,14} & \multirow{3}{*}{0,00} & \\
\hline & B-22-25 yaş & 240 & 31,85 & 4,13 & & & $\begin{array}{l}C>A \\
C>B \\
B>A\end{array}$ \\
\hline & C-26-30 yaş & 242 & 32,97 & 3,98 & & & \\
\hline \multirow{3}{*}{$\begin{array}{c}\text { Yaşlıya yönelik } \\
\text { olumsuz ayrımcılık }\end{array}$} & A-18-21 yaş & 115 & 16,12 & 3,43 & \multirow{3}{*}{10,52} & \multirow{3}{*}{0,00} & $\begin{array}{l}C>A \\
C>B\end{array}$ \\
\hline & B-22-25 yaş & 240 & 16,36 & 3,26 & & & \\
\hline & C-26-30 yaş & 242 & 17,56 & 3,47 & & & \\
\hline \multirow{3}{*}{ YATÖ TOPLAM PUAN } & A-18-21 yaş & 115 & 81,77 & 8,35 & \multirow{3}{*}{20,73} & \multirow{3}{*}{0,00} & \\
\hline & B-22-25 yaş & 240 & 84,22 & 8,14 & & & $\mathrm{C}>\mathrm{B}$ \\
\hline & C-26-30 yaş & 242 & 87,45 & 8,23 & & & $\mathrm{~B}>\mathrm{A}$ \\
\hline
\end{tabular}

Katılımcıların yaşlının yaşamını sınırlama, yaşlıya yönelik olumlu ayrımcılık ve yaşlıya yönelik olumsuz ayrımcılık faktörleri puan ortalamaları ile YATÖ toplam puan ortalamalarının yaş grubuna göre anlamlı bir farklılık $(\mathrm{p}<0,05)$ gösterdiği belirlenmiştir. Buna göre 26-30 yaş grubunda bulunan katılımcılarda yaşlının yaşamını sınırlama faktörünün puan ortalaması, 18-21 
yaş grubunda bulunan katılımcılara göre anlamlı düzeyde daha yüksektir. Benzer şekilde, 2630 yaş grubunda bulunan katılımcıların yaşlıya yönelik olumsuz ayrımcılık faktörü puan ortalaması; 18-21 ve 22-25 yaş gruplarında bulunan katılımcıların puan ortalamasından anlamlı düzeyde daha yüksektir. Ayrıca yaşlıya yönelik olumlu ayrımcılık faktörü puan ortalamasının ve YATÖ toplam puan ortalamasının 26-30 yaş grubundaki katılımcılarda en yüksek; 18-21 yaş grubunda bulunan katılımcılarda ise en düşük olduğu tespit edilmiştir. Buna göre katılımcıların yaşı arttıkça yaşlıya yönelik olumlu ayrımcılık faktörü tutum puanlarının ve YATÖ toplam puan ortalamalarının da arttı̆̆ı anlaşılmaktadır.

Katılımcıların yaşlının yaşamını sınırlama faktörü puan ortalamalarının, medeni duruma göre anlamlı bir farklılık $(p>0,05)$ göstermediği tespit edilmiştir. Bununla birlikte medeni duruma göre; yaşlıya yönelik olumlu ayrımcılık ve yaşlıya yönelik olumsuz ayrımcılık faktörlerinin puan ortalamaları ile YATÖ toplam puan ortalamasının anlamlı bir farklılık $(\mathrm{p}<0,05)$ gösterdiği belirlenmiştir. Evli katılımcılarda yaşlıya yönelik olumlu ayrımcılık ve yaşlıya yönelik olumsuz ayrımcılık faktörlerinin ve YATÖ toplam puan ortalamasının, bekâr katılımcılara kıyasla anlamlı düzeyde daha yüksek olduğu tespit edilmiştir.

Tablo 4. Yaşlı Ayrımcılığı Tutum Puanlarının öğrenim Durumuna Göre

\begin{tabular}{|c|c|c|c|c|c|c|c|}
\hline Alt Boyut & öğrenim Durumu & $\mathbf{n}$ & $\overline{\mathbf{x}}$ & SS & $\mathbf{F}$ & $\mathbf{p}$ & $\begin{array}{l}\text { Anlamlı } \\
\text { Fark }\end{array}$ \\
\hline \multirow{3}{*}{$\begin{array}{c}\text { Yaşlının yaşamını } \\
\text { sinırlama }\end{array}$} & A- İlkokul \& ortaokul & 55 & 34,22 & 5,26 & \multirow{3}{*}{9,90} & \multirow{3}{*}{0,00} & $\mathrm{~B}>\mathrm{A}$ \\
\hline & B-Lise & 241 & 36,03 & 4,14 & & & \multirow[t]{2}{*}{$\mathrm{C}>\mathrm{A}$} \\
\hline & C-Üniversite & 301 & 36,83 & 3,92 & & & \\
\hline \multirow{4}{*}{$\begin{array}{l}\text { Yaşlıya yönelik } \\
\text { olumlu ayrımcllık }\end{array}$} & A-ìlkokul \& ortaokul & 55 & 32,25 & 4,63 & \multirow{3}{*}{2,84} & \multirow{3}{*}{0,06} & \multirow{3}{*}{-} \\
\hline & B-Lise & 241 & 31,48 & 4,37 & & & \\
\hline & C-Üniversite & 301 & 32,35 & 4,18 & & & \\
\hline & A-i̇lkokul \& ortaokul & 55 & 15,31 & 3,69 & \multirow{3}{*}{7,74} & \multirow{3}{*}{0,00} & $\mathrm{~B}>\mathrm{A}$ \\
\hline \multirow{3}{*}{$\begin{array}{c}\text { Yaşlıya yönelik } \\
\text { olumsuz ayrımcılık }\end{array}$} & B-Lise & 241 & 16,63 & 3,28 & & & $C>A$ \\
\hline & C-Üniversite & 301 & 17,21 & 3,43 & & & \\
\hline & A-İlkokul \& ortaokul & 55 & 81,78 & 9,11 & \multirow{3}{*}{9,44} & \multirow{3}{*}{0,00} & \\
\hline \multirow[t]{2}{*}{$\begin{array}{l}\text { YATÖ TOPLAM } \\
\text { PUAN }\end{array}$} & B-Lise & 241 & 84,15 & 7,84 & & & \\
\hline & C-Üniversite & 301 & 86,39 & 8,63 & & & \\
\hline
\end{tabular}

Tablo 4 incelendiğinde; katılımcıların yaşlıya yönelik olumlu ayrımcılık puan ortalamasının öğrenim durumuna göre anlamlı bir farklılık $(p>0,05)$ göstermediği anlaşılmaktadır. Buna rağmen öğrenim durumuna göre; yaşlının yaşamını sınırlama ve yaşlıya yönelik olumsuz ayrımcılık faktörlerinin puan ortalamaları ile YATÖ toplam puan ortalamasının anlamlı bir 
farklılık $(\mathrm{p}<0,05)$ gösterdiği tespit edilmiştir. Lise ve üniversite mezunu katılımcıların, ilkokul ve ortaokul mezunu olan katılımcılara kıyasla yaşlının yaşamını sınırlama ve yaşlıya yönelik olumsuz ayrımcılık faktörlerinin puan ortalamaları ile YATÖ toplam puan ortalamasının anlamlı olarak daha yüksek olduğuna ulaşılmıştır.

Tablo 5. Yaşlı Ayrımcılığı Tutum Puanlarının Yaşadığı Yerleşim Yerine Göre Karşılaştırılması

\begin{tabular}{|c|c|c|c|c|c|c|c|}
\hline Alt Boyut & Yerleşim Yeri & $\mathbf{n}$ & $\overline{\mathbf{x}}$ & SS & $\mathbf{F}$ & p & $\begin{array}{l}\text { Anlamlı } \\
\text { Fark }\end{array}$ \\
\hline \multirow{3}{*}{$\begin{array}{l}\text { Yaşlının yaşamını } \\
\text { sınırlama }\end{array}$} & $\begin{array}{c}\text { A- Kasaba \& Köy/ } \\
\text { Mahalle }\end{array}$ & 86 & 35,48 & 3,69 & \multirow{3}{*}{4,92} & \multirow{3}{*}{0,01} & $\mathrm{C}>\mathrm{A}$ \\
\hline & B- Manisa il merkezi & 324 & 36,05 & 4,60 & & & \\
\hline & C-İlçe & 187 & 37,01 & 3,60 & & & \\
\hline \multirow{3}{*}{$\begin{array}{l}\text { Yaşlıya yönelik } \\
\text { olumlu ayrımcılık }\end{array}$} & $\begin{array}{c}\text { A- Kasaba \& Köy/ } \\
\text { Mahalle }\end{array}$ & 86 & 32,02 & 4,98 & \multirow{3}{*}{1,10} & \multirow{3}{*}{0,33} & \\
\hline & B- Manisa il merkezi & 324 & 31,77 & 4,34 & & & - \\
\hline & C-ìlçe & 187 & 32,35 & 3,93 & & & \\
\hline \multirow{3}{*}{$\begin{array}{c}\text { Yaşlıya yönelik } \\
\text { olumsuz ayrımcılık }\end{array}$} & $\begin{array}{c}\text { A- Kasaba \& Köy/ } \\
\text { Mahalle }\end{array}$ & 86 & 16,00 & 3,36 & \multirow{3}{*}{4,70} & \multirow{3}{*}{0,01} & $\mathrm{C}>\mathrm{A}$ \\
\hline & B- Manisa il merkezi & 324 & 16,71 & 3,54 & & & \\
\hline & C-İlçe & 187 & 17,33 & 3,20 & & & \\
\hline \multirow{3}{*}{$\begin{array}{l}\text { YATÖ TOPLAM } \\
\text { PUAN }\end{array}$} & $\begin{array}{c}\text { A- Kasaba \& Köy/ } \\
\text { Mahalle }\end{array}$ & 86 & 83,50 & 7,49 & \multirow{3}{*}{5,63} & \multirow{3}{*}{0,00} & $\mathrm{C}>\mathrm{A}$ \\
\hline & B- Manisa il merkezi & 324 & 84,53 & 9,09 & & & \\
\hline & C-İlçe & 187 & 86,69 & 7,57 & & & \\
\hline
\end{tabular}

Katılımcıların yaşlıya yönelik olumlu ayrımcılık puan ortalamasının yaşanılan yerleşim yerine göre anlamlı bir farklılık ( $p>0,05)$ göstermediği anlaşılmaktadır. Buna karşın yaşlının yaşamını sınırlama ve yaşlıya yönelik olumsuz ayrımcılık faktörlerinin puan ortalamaları ile YATÖ toplam puan ortalamasının yaşanılan yerleşim yerine göre anlamlı bir farklılık $(\mathrm{p}<0,05)$ gösterdiği belirlenmiştir. İlçe merkezlerinde yaşayan katılımcıların, kasaba ve köy/mahalle merkezlerinde yaşayan katılımcılara kıyasla yaşlının yaşamını sınırlama ve yaşlıya yönelik olumsuz ayrımcılık faktörlerinin puan ortalamaları ile YATÖ toplam puan ortalaması anlamlı olarak daha yüksektir. 
Tablo 6. Yaşlı Ayrımcılığı Tutum Puanlarının İstihdam Durumuna Göre Karşılaştırılması

\begin{tabular}{|c|c|c|c|c|c|c|c|}
\hline Alt Boyut & İstihdam Durumu & $\mathbf{n}$ & $\overline{\mathbf{x}}$ & SS & $\mathbf{F}$ & $\mathrm{p}$ & $\begin{array}{c}\text { Anlamlı } \\
\text { Fark }\end{array}$ \\
\hline \multirow{3}{*}{$\begin{array}{c}\text { Yaşlının yaşamını } \\
\text { sinırlama }\end{array}$} & A- Çalışmıyor & 219 & 36,08 & 4,28 & \multirow{3}{*}{1,32} & \multirow{3}{*}{0,27} & \multirow{3}{*}{ - } \\
\hline & B-Kamu & 145 & 36,00 & 4,26 & & & \\
\hline & C-Özel \& yarı zamanlı & 233 & 36,62 & 4,11 & & & \\
\hline \multirow{4}{*}{$\begin{array}{l}\text { Yaşlıya yönelik } \\
\text { olumlu ayrımcılık }\end{array}$} & A- Çalışmıyor & 219 & 31,00 & 4,42 & \multirow{3}{*}{9,68} & \multirow{3}{*}{0,06} & \multirow{3}{*}{$\begin{array}{l}\mathrm{B}>\mathrm{A} \\
\mathrm{C}>\mathrm{A}\end{array}$} \\
\hline & B-Kamu & 145 & 32,34 & 4,30 & & & \\
\hline & C-Özel \& yarı zamanlı & 233 & 32,70 & 4,07 & & & \\
\hline & A- Çalışmıyor & 219 & 16,61 & 3,26 & \multirow{3}{*}{2,74} & \multirow{3}{*}{0,07} & \multirow{3}{*}{ - } \\
\hline \multirow[t]{3}{*}{$\begin{array}{c}\text { Yaşlıya yönelik } \\
\text { olumsuz ayrımcılık }\end{array}$} & B-Kamu & 145 & 17,38 & 3,66 & & & \\
\hline & C-Özel \& yarı zamanlı & 233 & 16,62 & 3,42 & & & \\
\hline & A- Çalışmıyor & 219 & 83,68 & 8,22 & \multirow{3}{*}{4,60} & \multirow{3}{*}{0,01} & $\mathrm{C}>\mathrm{A}$ \\
\hline \multirow[t]{2}{*}{$\begin{array}{l}\text { YATÖ TOPLAM } \\
\text { PUAN }\end{array}$} & B-Kamu & 145 & 85,72 & 9,12 & & & \\
\hline & C-Özel \& yarı zamanlı & 233 & 85,93 & 8,19 & & & \\
\hline
\end{tabular}

Yukarıda yer alan tablo incelendiğinde, yaşlının yaşamını sınırlama ve yaşlıya yönelik olumsuz ayrımcılık puan ortalamalarının istihdam durumuna göre anlamlı bir farklılık (p>0,05) göstermediği anlaşılmaktadır. Buna karşın yaşlıya yönelik olumlu ayrımcılık faktörü puan ortalaması ile YATÖ toplam puan ortalamasının istihdam duruma göre anlamlı bir farklılık $(p<0,05)$ gösterdiği belirlenmiştir. Kamuda, özel sektörde ve yarı zamanlı işlerde çalışan katılımcıların yaşlıya yönelik olumlu ayrımcılık puan ortalamaları, herhangi bir işte çalışmayan katılımcıların puan ortalamasından anlamlı olarak daha yüksektir. Ayrıca, özel sektörde ve yarı zamanlı işlerde çalışan katılımcıların YATÖ toplam puan ortalaması, herhangi bir işte çalışmayan katılımcıların puan ortalamasından anlamlı olarak daha yüksektir.

Tablo 7. Yaşlı Ayrımcılığı Tutum Puanlarının Aylık Gelire Göre Karşılaştırılması

\begin{tabular}{|c|c|c|c|c|c|c|c|}
\hline Alt Boyut & Aylık Gelir & $\mathbf{n}$ & $\overline{\mathbf{x}}$ & SS & $\mathbf{F}$ & $\mathbf{p}$ & $\begin{array}{c}\text { Anlamlı } \\
\text { Fark }\end{array}$ \\
\hline \multirow{6}{*}{$\begin{array}{l}\text { Yaşlının yaşamını } \\
\text { sinırlama }\end{array}$} & A-1000TL ve altı & 47 & 34,89 & 4,35 & \multirow{6}{*}{4,84} & \multirow{6}{*}{0,00} & \multirow{6}{*}{$\begin{array}{l}\mathrm{D}>\mathrm{A} \\
\mathrm{E}>\mathrm{A} \\
\mathrm{F}>\mathrm{A}\end{array}$} \\
\hline & B-1001-2500TL & 116 & 35,90 & 4,38 & & & \\
\hline & C-2501-3500TL & 182 & 35,62 & 4,39 & & & \\
\hline & D-3501-5000TL & 143 & 37,24 & 3,92 & & & \\
\hline & E-5001-6000TL & 48 & 37,63 & 2,95 & & & \\
\hline & F-6001TL ve üzeri & 61 & 36,64 & 4,07 & & & \\
\hline
\end{tabular}




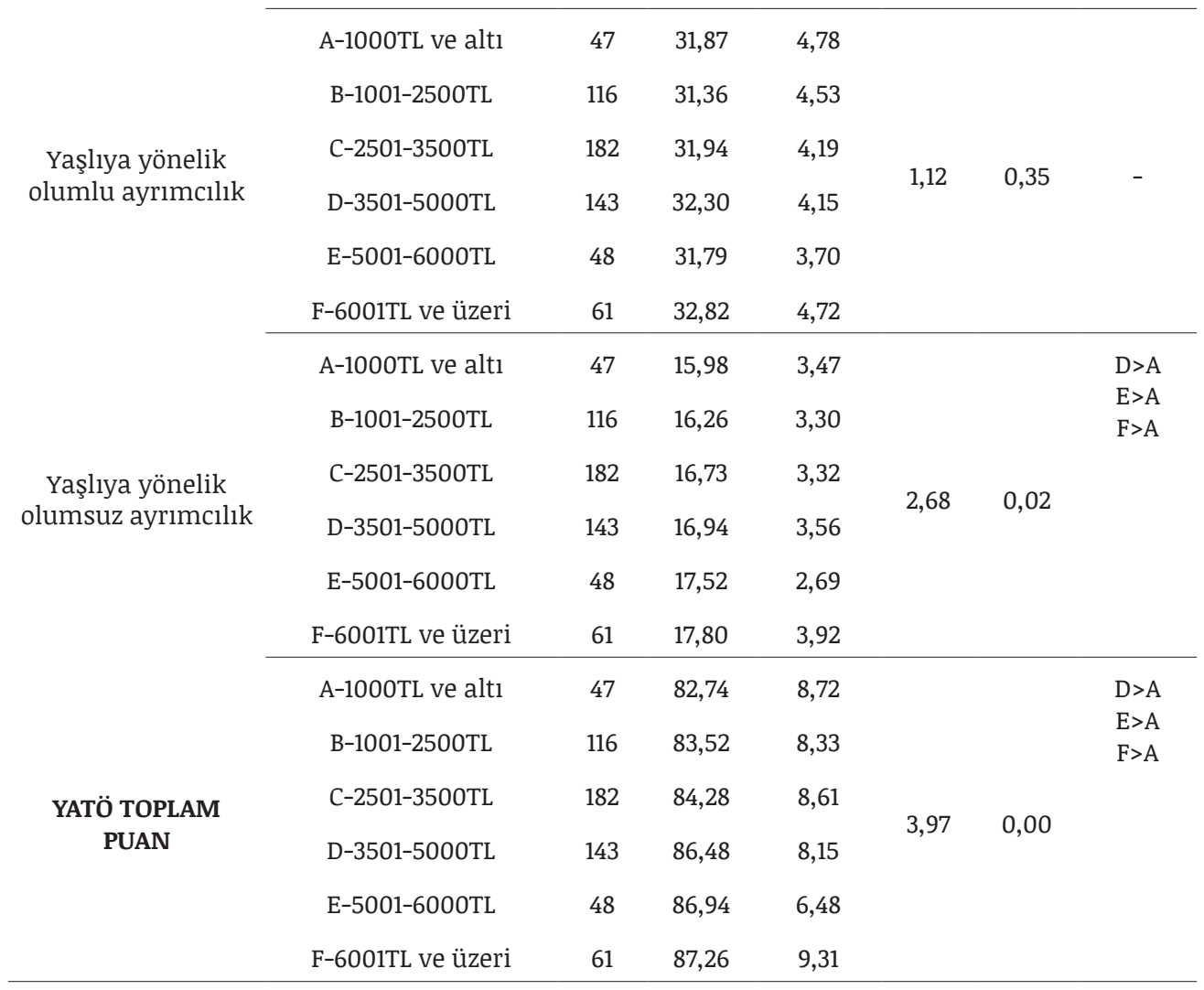

Katılımcılar gelir düzeyine göre değerlendirildiğinde; yaşlıya yönelik olumlu ayrımcılık puan ortalamasının anlamlı bir farklılık $(p>0,05)$ göstermediği anlaşılmaktadır. Buna rağmen gelir düzeyine göre; yaşlının yaşamını sınırlama ve yaşlıya yönelik olumsuz ayrımcılık faktörlerinin puan ortalamaları ile YATÖ toplam puan ortalamasının anlamlı bir farklılık $(p<0,05)$ gösterdiği belirlenmiştir. 3501 TL-5000 TL arası, 5001 TL-6000 TL arası, 6001 TL ve üzeri aylık gelire sahip olan katılımcıların yaşlının yaşamını sınırlama ve yaşlıya yönelik olumsuz ayrımcılık faktörlerinin puan ortalaması ile YATÖ toplam puan ortalaması, 1000 TL ve altı aylık gelire sahip olan katılımcıların puan ortalamalarından anlamlı olarak daha yüksektir.

Katılımcıların yaşlının yaşamını sınırlama, yaşlıya yönelik olumlu ayrımcılık ve yaşlıya yönelik olumsuz ayrımcılık faktörlerinin puan ortalamaları ile YATÖ toplam puan ortalamasının yaşadıkları aile tipine göre anlamlı bir farklılık ( $>0,05)$ göstermediği anlaşılmaktadır. Çekirdek, geniş ve tek ebeveynli ailelerde yaşayanlar ile yalnız yaşadığını ifade eden katılımcıların yaşlı ayrımcılığı ile ilgili tutumlarının benzer olduğu anlaşılmıştır. Ayrıca yaşlının yaşamını sınırlama, yaşlıya yönelik olumlu ayrımcılık ve yaşlıya yönelik olumsuz ayrımcılık faktörlerinin puan ortalamaları ile YATÖ toplam puan ortalamasının ailede yaşlı bir bireyle birlikte yaşama duruma göre anlamlı bir farklılık $(p>0,05)$ göstermediği de tespit edilmiştir. Dolayı- 
sıyla yaşlı ayrımcılığı ile ilişkili tutumlar ailede birlikte yaşanılan yaşlı bir bireyin bulunma durumuna göre de farklılık göstermemektedir.

Katılımcıların yaşlının yaşamını sınırlama, yaşlıya yönelik olumlu ayrımcılık ve yaşlıya yönelik olumsuz ayrımcılık faktörleri puan ortalamaları ile YATÖ toplam puan ortalamasının yaşlı bireylerle bir araya gelme sıklığına göre anlamlı bir farklılık $(p>0,05)$ göstermediği anlaşılmaktadır. Bir başka ifadeyle yaşlı ayrımcılığı ile ilişkili tutumlar yaşlı bireylerle bir araya gelme sıklığına göre farklılık göstermemektedir. Buna göre her gün, haftada bir, 15 günde bir, ayda bir, bayramlarda ve yılda bir yaşlılar ile görüştüğünü veya hiç görüşmediğini belirten katılımcıların yaşlı ayrımcılığı ile ilgili tutumlarının benzer olduğu gözlenmiştir.

Tablo 8. Yaşlı Ayrımcılığı Tutum Puanlarının Tercih Hakkı Olsa Yaşlı Bir Birey ile Aynı Evde Yaşama İsteğine Göre Karşılaştırılması

\begin{tabular}{|c|c|c|c|c|c|c|c|}
\hline Alt Boyut & $\begin{array}{c}\text { Aynı Evde } \\
\text { Yaşama İsteği }\end{array}$ & $\mathbf{n}$ & $\overline{\mathbf{X}}$ & SS & $\mathbf{F}$ & p & $\begin{array}{l}\text { Anlamlı } \\
\text { Fark }\end{array}$ \\
\hline \multirow{3}{*}{$\begin{array}{l}\text { Yaşlının yaşamını } \\
\text { sınırlama }\end{array}$} & A-Evet & 309 & 36,74 & 4,02 & \multirow{3}{*}{6,92} & \multirow{3}{*}{0,00} & $A>B$ \\
\hline & B-Hayır & 96 & 34,94 & 5,41 & & & $C>B$ \\
\hline & C-Kararsız & 192 & 36,18 & 3,67 & & & \\
\hline \multirow{3}{*}{$\begin{array}{l}\text { Yaşlıya yönelik } \\
\text { olumlu ayrımcılık }\end{array}$} & A-Evet & 309 & 33,22 & 4,12 & \multirow{3}{*}{32,98} & \multirow{3}{*}{0,00} & \\
\hline & B-Hayır & 96 & 29,68 & 4,52 & & & $\begin{array}{l}A>B \\
A>C\end{array}$ \\
\hline & C-Kararsız & 192 & 31,16 & 3,85 & & & $C>B$ \\
\hline \multirow{3}{*}{$\begin{array}{c}\text { Yaşlıya yönelik } \\
\text { olumsuz ayrımcılık }\end{array}$} & A-Evet & 309 & 17,12 & 3,61 & \multirow{3}{*}{4,19} & \multirow{3}{*}{0,02} & $A>B$ \\
\hline & B-Hayır & 96 & 15,99 & 3,47 & & & $\mathrm{C}>\mathrm{B}$ \\
\hline & C-Kararsız & 192 & 16,69 & 3,05 & & & \\
\hline \multirow{3}{*}{$\begin{array}{l}\text { YAŞLI AYRIMCILIĞI } \\
\text { TUTUMU }\end{array}$} & A-Evet & 309 & 87,08 & 8,55 & \multirow{3}{*}{25,33} & \multirow{3}{*}{0,00} & $A>B$ \\
\hline & B-Hayır & 96 & 80,60 & 9,39 & & & $\begin{array}{l}A>C \\
C>B\end{array}$ \\
\hline & C-Kararsız & 192 & 84,03 & 6,74 & & & \\
\hline
\end{tabular}

Yukarıda yer alan tablo incelendiğinde; tercih hakkı olsa yaşlı bir birey ile aynı evde yaşamayı isteme durumuna göre yaşlının yaşamını sınırlama, yaşlıya yönelik olumlu ayrımcılık ve yaşlıya yönelik olumsuz ayrımcıllk faktörleri puan ortalamaları ile YATÖ toplam puan ortalamasının anlamlı bir farklılık $(\mathrm{p}<0,05)$ gösterdiği anlaşılmaktadır. Yaşlı bir birey ile aynı evde yaşamak isteyen ve bu konuda kararsız olduğunu ifade eden katılımcıların yaşlının yaşamını sınırlama ve yaşlıya yönelik olumsuz ayrımcılık puan ortalamaları, yaşlı bir birey ile aynı evde yaşamak istemeyen katılımcıların puan ortalamasından anlamlı olarak daha yüksektir. Yaşlı bir birey ile aynı evde yaşamak isteyen katılımcıların yaşlıya yönelik olumlu ayrımcılık ve YATÖ toplam puan ortalamaları, yaşlı bir birey ile aynı evde yaşamak istemeyen ve bu konuda kararsız olduğunu ifade eden katılımcıların puan ortalamalarından anlamlı olarak 
daha yüksektir. Yaşlı bir birey ile aynı evde yaşama konusunda kararsız olduğunu ifade eden katılımcıların yaşlıya yönelik olumlu ayrımcılık ve YATÖ toplam puan ortalamaları ise sadece yaşlı bir birey ile aynı evde yaşamak istemeyen katılımcıların puan ortalamalarından daha yüksek olduğu tespit edilmiştir.

\section{Tartışma}

Yaşlı nüfusun tüm dünyada düzenli olarak arttığı ve yaşlılar ile toplumun diğer kesimleri arasındaki ilişkinin çeşitlendiği bir dönemde Manisa ilinde gerçekleştirilen bu araştırmada, katılımcıların YATÖ toplam puan ortalamaları 85,06 $\pm 8,49$ olarak tespit edilmiştir. Ölçekten alınabilecek minimum (23) ve maksimum (115) puan aralıkları göz önüne alındığında; katılımcıların ortalamanın üzerinde olumlu bir tutuma sahip oldukları ifade edilebilir. Türkiye'de bu çalışmadaki yaş aralığında bulunan üniversite öğrencileri arasında yapılan farklı çalışmalarda da benzer sonuçlara ulaşıldığı görülmektedir (Güven ve ark., 2012; Ceylan ve Öksüz, 2015; Boz ve ark., 2017; Zaybak ve ark., 2017; Kaçan ve ark., 2018; Başaran, 2018; Kurtkapan, 2019). Bu çalışmalarda üniversite öğrenimi gören katılımcıların yaşlı ayrımcılığına karşı tutumları olumludur; ancak nispeten olumlu düzeyde $(70,69 \pm 8,72 ; 69,57 \pm 8,27 ; 68,82 \pm 8,54)$ değerlendirilen araştırma sonuçları da bulunmaktadır (Ucun ve ark., 2015; Altay ve Aydın, 2015; Altun ve Demirel, 2020). Türkiye'de benzer yaş aralığında gerçekleştirilen araştırmaların pek çoğunda yaşlı ayrımcılığına yönelik tutum puanlarının yüksek olduğu ifade edilebilir. Uluslararası literatürde genç nüfusun yaşlılara yönelik olumsuz tutuma sahip olduğunu gösteren araştırmalar da mevcuttur (Slevin, 1991; Kite ve ark., 2005). Ancak diğerkâmlık, hoşgörü ve ataerkillik etrafında şekillenen Anadolu kültüründeki toplumsal yapı; yaşlıları sevmeye, onlara saygı duymaya ve onları koruyup kollamaya yönelik duyguyu, düşünceyi ve davranışları da içinde barındırmaktadır (Pehlivan, 2017; Ersoy, 2006). Bu algı ve tutum Türkiye'deki genç nüfusun yaşlı nüfusa yönelik ayrımcılıktan uzak, kabullenici ve destekleyici bir anlayış içinde olmasını sağlamaktadır diyebiliriz. Araştırma sonuçları cinsiyet değişkenine göre değerlendirildiğinde; katılımcıların YATÖ toplam puan ortalamaları anlamlı bir farklılık $(p>0,05)$ göstermemektedir. Buna rağmen kadın katılımcıların yaşlının yaşamını sınırlama ve yaşlıya yönelik olumsuz ayrımcılık faktörlerinin puan ortalamaları erkeklere oranla daha yüksek bulunmuştur. Erkeklerin sadece olumlu ayrımcılık faktörü puan ortalamaları kadınlara göre daha yüksek çıkmıştır. Üniversite öğrencileri arasında yapılan farklı araştırmalarda da kadın katılımcıların yaşlı ayrımcılığı tutum puanlarının erkek katılımcılardan daha yüksek olduğu tespit edilmiştir (Vefikuluçay, 2008; Canatan, 2009; Yllmaz ve Özkan, 2010; Karadağ ve ark., 2012; Adıbelli ve ark., 2013; Boz ve ark., 2017). Buna karşın bazı araştırmalarda (Soyuer ve ark., 2010; Zaybak ve ark., 2017) erkeklerin yaşlı ayrımcılığı tutum puanlarının kadınlara oranla daha yüksek olduğu belirlenmiş; ancak gruplar arasında anlamlı bir fark bulunamamıştır. Alt ölçek puan ortalamalarının dikkate alındığı sadece bir çalışmada (Altay ve Aydın, 2015) yaşlının yaşamının sınırlanması faktörünün puanının kadınlara oranla erkeklerde daha yüksek olduğu tespit edilmiş ve gruplar ara- 
sında anlamlı bir fark bulunmuştur. Kadınların yaşlı ayrımcılığı tutum puanlarının yüksek olarak tespit edildiği çalışmalarda bu durumun kadınların toplum ve kültür içindeki bakım verici rolünden kaynaklanabileceği ifade edilmektedir (Altay ve Aydın, 2015; Ucun ve ark., 2015). Burada toplumsal cinsiyete dayalı işbölümünden ve hiyerarşiden kaynaklanan bakım verici rolüne ek olarak, kadınlara yüklenen farklı toplumsal sorumluluklardan da bahsedilebilir. Örneğin; kadının yerinin evi olduğu, evin işlerinden sorumlu olduğu, eşine veya büyüklerine saygı göstermesi ve onlara karşı daha uysal, sadık, anlayışlı, merhametli ve güvenilir olması gerektiği gibi toplumsal algı ve kabuller kadınların yaşlılara karşı daha olumlu bir tutuma sahip olmalarını sağlıyor olabilir.

Katılımcıların YATÖ toplam puan ortalamaları incelendiğinde; 26-30 yaş grubu katılımcıların 18-21 ve 22-25 yaş grubu katılımcılara oranla daha yüksek puan ortalamasına sahip oldukları anlaşılmaktadır. Bu durumda katılımcıların yaşları arttıkça yaşlılara yönelik daha olumlu bir tutuma sahip oldukları görülmektedir. Benzer şekilde üniversite öğrencileri arasında yapılan araştırmalarda da katılımcıların yaşları ya da sınıf düzeyleri arttıkça yaşlılara yönelik daha olumlu bir tutuma sahip oldukları aktarılmıştır (Söderhamn ve ark., 2001; Vefikuluçay, 2008; Hughes ve ark., 2008; Yllmaz ve Özkan, 2010; Ceylan ve Öksüz, 2015). Öte yandan bazı araştırmalarda yaş ya da sınıf değişkeninin yaşlılara yönelik olumlu tutumda etkili olmadığı da tespit edilmiştir (Soyuer ve ark., 2010; Olak ve Tümer, 2018). Fakat bu mevcut araştırma sonuçlarının genel olarak literatürdeki diğer çalışmalarla örtüştüğü ifade edilebilir. Bu durum katılımcıların yaş aldıkça yaşlılarla karşılaşma ihtimalinin ve etkileşim pratiklerinin artmasıyla veya yaşlı bireylere yönelik empati yeteneklerinin gelişmesiyle açıklanabilir. Bu durum ayrıca katılımcıların hayatın olağan akışı içinde ya da eğitim süreçlerinde edindikleri yeni bilgi ve bakış açılarıyla ilişkili olarak da açıklanabilir. Nitekim araştırmada katılımcıların eğitim seviyesi arttıkça yaşlılara yönelik olumsuz tutumun azaldığı görülmektedir. Lise ve üniversite mezunu katılımcıların yaşlının yaşamını sınırlama ve yaşlıya yönelik olumsuz ayrımcılık faktörleri puan ortalamaları ile YATÖ toplam puan ortalaması, ilkokul ve ortaokul mezunu olan katılımcılara oranla daha yüksek tespit edilmiştir. Bu araştırmanın sonuçlarından farklı olarak bazı çalışmalarda katılımcıların eğitim durumu ile yaşlı ayrımcılığı tutum puanları arasında anlamlı bir fark tespit edilememiştir (Kaçan ve ark., 2018; Sülüker ve Türkoğlu, 2021). Öte yandan üniversite mezunu olan katılımcıların YATÖ toplam puan ortalamalarının ilköğretim mezunu olanlara oranla anlamlı düzeyde daha düşük olarak tespit edildiği çalışmalar da bulunmaktadır (Ünalan ve ark., 2012). Fakat genel olarak katılımcıların eğitim düzeyleri ile yaşlı ayrımcılığı tutum puanları arasında pozitif yönde bir ilişki söz konusudur.

Katılımcıların yaşlının yaşamını sınırlama ve yaşlıya yönelik olumsuz ayrımcılık faktörleri puan ortalamaları ile YATÖ toplam puan ortalaması yaşanılan yerleşim yerine göre anlamlı farklılıklar göstermektedir. Buna göre ilçede yaşayan katılımcıların tutum puanları, kasaba ve köy/mahalle merkezlerinde yaşayan katılımcılara oranla daha yüksektir. Türkiye'de yaşlı 
ayrımcılığına yönelik yapılan araştırmalarda farklı sonuçların ortaya çıktığı görülmektedir. Örneğin Ucun ve arkadaşları (2015) tarafından yapılan araştırmada, mevcut araştırmanın sonucuna benzer bir sonuç ortaya çlkmıştır. Fakat mevcut çalışma sonucunun aksine, ilçede yaşayan katılımcıların YATÖ toplam puan ortalamasının düşük düzeyde olduğunun tespit edildiği çalışmalar (Altay ve Aydın, 2015) da mevcuttur. Benzer şekilde Kaçan ve arkadaşları (2018) ile Yllmaz ve Özkan (2010) tarafından yapılan araştırmalarda köyde yaşayan katılımcıların yaşlı ayrımcılığına yönelik tutumunun, diğer yerleşim yerlerinde yaşayanlara oranla daha olumlu olduğu tespit edilmiştir. Olak ve Tümer (2018) ise kırsal alanda yaşayan katılımcıların kentsel alanda yaşayanlara oranla daha yüksek puan ortalamalarına sahip olduğunu ifade etmektedir. Ancak bu konuda ortaya çıkan en yaygın sonuç, katılımcıların yaşlı ayrımcılığı tutum puanlarının yaşadıkları yerleşim yerine göre farklılık göstermiyor olmasıdır (Soyuer ve ark., 2010; Özbek Yazıcı ve ark., 2015; Dinçer ve ark., 2016; Boz ve ark., 2017; Kurtkapan, 2019). Bu durum toplumun alt kültür özelliklerinden ziyade temel/ana kültür özellikleri ile açıklanmaktadır (Tekin Kaya ve Örsal, 2018). Ne var ki bu sonuçlar makro düzeyden ziyade mikro düzeyde de açıklanabilir. Buna göre katılımcıların yaşlı ayrımcılığına yönelik tutumlarında, doğup büyüdükleri ve/veya yaşadıkları yerleşim yerinden ve kültürden bağımsız olarak yaşlılarla olan deneyimlerinin de etkili olabileceği ileri sürülebilir.

Katılımcıların yaşlılara yönelik olumlu ayrımcılık faktörü puanı ile YATÖ toplam puan ortalamasının istihdam durumuna göre anlamlı bir farklılık gösterdiği belirlenmiştir. Buna göre; kamuda, özel sektörde ve/veya yarı zamanlı işlerde çalışan katılımcıların yaşlıya yönelik olumlu ayrımcılık puan ortalamaları ile özel sektörde ve/veya yarı zamanlı işlerde çalışan katılımcıların YATÖ toplam puan ortalaması, herhangi bir işte çalışmayan katılımcıların puan ortalamasından anlamlı olarak daha yüksektir. Türkiye'de yaşlı ayrımcılığı ile ilgili yapılan çalışmaların genellikle üniversite öğrencileriyle gerçekleştirilmiş olması ve toplumun diğer kesimleriyle gerçekleştirilen araştırmalarda istihdam değişkeninin incelemeye dâhil edilmemiş olması nedeniyle literatürde bu araştırma sonuçlarını karşılaştıracak herhangi bir veriye ulaşılamamıştır. Fakat bu sonuç ekonomik olarak bağımsızlığına kavuşmuş, kimlik/benlik oluşumunu tamamlamış ve psikososyal açıdan yakınlık kurma eğiliminde (Erikson, 2014) olan bireylerin yaşlılara yönelik daha olumlu tutum sergiledikleri şeklinde yorumlanabilir. Nitekim bu gençler geleceğe yönelik kaygıdan kısmen arınmış, daha özgüvenli, kendilerini gerçekleştirme yolunda ve geleceğe yönelik mikro bağlamdan mezzo bağlama yönelen beklentiler içinde olan bireyler olarak değerlendirilebilir. Bu bakış açısıyla katılımcıların yaşlılara yönelik daha aile odaklı bir tutum geliştirmeleri olasıdır. Benzer şekilde; katılımcıların aylık gelir durumlarına göre bir değerlendirme yapıldığında aylık 3501 TL ve üzeri gelire sahip olan katılımcıların yaşlılara yönelik tutum puanları daha yüksek bulunmuştur. Bu sonuçtan hareketle ekonomik refah düzeyi arttıkça yaşlılara yönelik tutumun da olumlu düzeyde arttığı ifade edilebilir. 
Bu çalışmada katılımcıların yaşlı ayrımcılığına ilişkin tutumlarının yaşanılan aile tipine göre farklılık göstermediği bulunmuştur. Literatürde buna benzer sonuçlar (Soyuer ve ark., 2010; Ünalan ve ark., 2012; Altay ve Aydın, 2015; Köse, ve ark., 2015) olduğu gibi; çekirdek aile tipine sahip olan katılımcıların geniş aile tipine sahip olan katılımcılara oranla yaşlının yaşamını sınırlama tutum puanının daha yüksek olduğu araştırmalar da mevcuttur (Dinçer, ve ark., 2016; Kaçan ve ark., 2018; Sülüker ve Türkoğlu, 2021). Bu durum geniş aile tipine sahip olan katılımcıların; gündelik yaşamda yaşlı bireylerle daha fazla etkileşim içinde olmaları, yaşam pratiklerinde olumsuz deneyimlerin ön plana çıkıyor olması ya da daha bağımsız veya bireysel bir yaşam sürdürme istekleri ile açıklanabilir. Bu sonuçların nedenselliği ile ilgili olarak geleneksel aile yapısında hâkim olan tahakküme dayalı baskıcı, otoriter, ataerkil ve hiyerarşik ilişkilerin bireyler üzerindeki olumsuz etkilerinin de göz ardı edilmemesi oldukça önemlidir (Başkurt, 2002; Çerik, 2002; Turğut, 2017).

Öte yandan bu çalışmada, katılımcıların yaşlı ayrımcılığına ilişkin tutumlarının ailede birlikte yaşanılan yaşlı bir bireyin bulunma durumuna göre farklılık göstermediği de tespit edilmiştir. Literatürdeki bazı çalışmalarda (Ayoğlu ve ark., 2014; Özbek Yazıcı ve ark., 2015; Köse ve ark., 2015; Ceylan ve Öksüz, 2015) bu çalışmadakine benzer sonuçların yer aldığı görülmektedir. Bu çalışmada katılımcıların yaşlı bireylerle bir araya gelme sıklığının yaşlının yaşamını sınırlama, yaşlıya yönelik olumlu/olumsuz ayrımcılık faktörleri puan ortalamaları ile YATÖ toplam puan ortalamasında anlamlı bir farklılık göstermediği tespit edilmiştir. Daha önce yapılmış çalışmalarda bu araştırma sonuçlarına benzer bir sonuç bulunmamakla birlikte katılımcıların yaşlılarla karşılaşma sıklığının yaşlı ayrımcılığına yönelik tutum puanlarının yükselmesine katkı sağladığı ifade edilmektedir (Vefikuluçay, 2008; Boz ve ark., 2017). Bir başka deyişle; yaşlılarla karşılaşma sıklığı katılımcıların olumlu tutumlarını etkilemektedir.

Son olarak bu çalışmada yaşlılarla aynı evde yaşamak isteyen katılımcıların yaşlının yaşamını sınırlama, yaşlıya yönelik olumlu ve olumsuz ayrımcılık faktörleri puan ortalamaları ile YATÖ toplam puan ortalamasının, yaşlı bir birey ile aynı evde yaşamak istemeyen katılımcıların puan ortalamalarından anlamlı olarak daha yüksek olduğu tespit edilmiştir. Kurtkapan (2019) tarafından gerçekleştirilen araştırmada da benzer sonuçlara ulaşılmıştır. Nitekim literatürde genel olarak yaşlılarla aynı evde yaşayan ya da yaşamak isteyen katılımcıların yaşlı ayrımcılığına yönelik tutum puanları daha yüksek tespit edilmektedir (Yılmaz ve Özkan, 2010; Ayaz Alkaya ve Birimoğlu Okuyan, 2017; Kaçan ve ark., 2018). Karaağaç ve arkadaşları (2019) tarafından yapılan bir araştırmaya katılan gençlerin \%48'inin yaşlı bir bireyle yaşamak istediği tespit edilmiştir. Katılımcılara bunun nedeni sorulduğunda; \%50'si yaşlıların deneyimlerinden yararlanıyor olduğunu, \%25’i ise yaşlıları sevdiğini ifade etmiştir. Bu sonuçlar kuşaklararası dayanışma yaklaşımında (Özmete, 2017) yer alan toplumdaki genç ve yaşlı kuşak arasındaki işbirliğine ve sevgiye dayalı dayanışma ilişkilerinin, katılımcı görüşlerine yansıdığını göstermektedir. Nitekim Yıldırım Usta ve arkadaşları (2012) tarafından yapılan bir araştırmada "sev- 
gi, destek olma, iyi anlaşma" gibi duygu ve durumların gençlerin yaşlılarla birlikte yaşama isteklerini olumlu yönde etkilediği sonucuna ulaşılmıştır.

\section{Sonuç ve Öneriler}

Bu araştırmanın sonucu, Türkiye'deki geleneksel, ataerkil ve alturistik toplumsal yapının araştırmaya katılan gençler üzerinde hâlâ etkin şekilde varlığını sürdürdüğünün bir göstergesi olarak değerlendirilebilir. Bu toplumsal yapı içindeki bireylerin geçmişten bugüne ailenin ve toplumun yaşça büyük üyelerine gösterdiği sevgi ve saygı bu araştırmada yaşlı ayrımcılığına yönelik ortaya çıkan olumlu algı ve tutumda karşılık bulmaktadır. Bu açıdan son yıllarda genç ve yaşlı nüfus arasında sıkça gündeme gelen kuşak çatışmasının, bu çalışma özelinde ayrımcılığı oluşturacak veya pekiştirecek bir noktada olmadığı ileri sürülebilir. Hatta katılımcıların yarıdan fazlasının ( $\mathrm{n}=311)$ tercih hakkı olsa yaşlı bir birey ile aynı evde yaşama isteğinde bulunuyor olması, iki taraf arasında kuşak çatışmasından ziyade kuşaklararası bir dayanışma olduğunu destekler niteliktedir. Kaldı ki çatışmanın hemen her zaman dilimindeki ve her toplum içindeki varlığı, çatışmayı değişme ya da gelişme açısından ontolojik bir boyuta taşımaktadır. Dolayısıyla araştırmanın sonuçlarına göre; iki kuşak arasında bir çatışma durumu olsa da genç nüfusun bu çatışmayı gelişme açısından bir fırsat olarak gördüğü ifade edilebilir. Nitekim yaşlı nüfusun sahip olduğu bilgi ve tecrübenin gelecek kuşaklara aktarılması, on binlerce yıldır süregelen insanlığın ortak mirasının da korunması ve sürdürülmesi anlamına gelmektedir. İşte tam bu noktada iki kuşak arasındaki aktarımın devamı için yapılması gereken farklı çalışmalar gündeme gelmektedir.

Aslında son yıllarda yaşlı dostu kentler ve/veya mekânlar adı altında yaşlı nüfusun toplumsal yaşama katılımını sağlamak amacıyla Agidel (Rusya), La Plata (Arjantin), Rockingham (Avustralya), Ottowa (Kanada), Kilkenny (İrlanda), Melville (Avustralya), Akita City (Japonya), Funchal (Portekiz) ve Tampere (Finlandiya) gibi kentlerde çeşitli uygulamalar ya da projeler gerçekleştirilmektedir. DSÖ’nün Yaşlı Dostu Şehirler Küresel Ağı tarafından belirlenen bu kentlerde; otobüs durakları, banklar, yüzme havuzları, kafeler, uğraşı bahçeleri, tuvaletler gibi mekânlar yaşlılara uygun olarak tasarlanmakta ve ayrıca çeşitli festivaller, konserler ve yarışmalar düzenlenmektedir (Caner ve ark., 2013). Bu uygulamalar yaşlılık veya yaşlanma çalışmalarında aktivite yaklaşımı/teorisi ile ifade edilen bakış açısını yansıtmaktadır. Fakat bu gelişmelerin içeriği, kapsamı ve işlevi göz önüne alındığında, daha çok yaşlı merkezli/odaklı ve sadece yaşlı nüfusa yönelik çalışmalar olduğu anlaşılmaktadır. Oysaki toplumsal bütünleşmenin, sosyal dengenin ve uyumun sağlanabilmesi için birlikte yaşam pratiklerinin oluşturulması, desteklenmesi ve yaygınlaştırılması gerekmektedir. Bunun için genç nüfusun da bu sürece dâhil edilebileceği farklı yapıların oluşturulması önem arz etmektedir. Bu noktada kuşaklararası dayanışma ağları veya destek grupları ile işlevsel bir mekanizma oluşturulabilir. İçinde bulunduğumuz pandemi sürecinde özellikle 65 yaş ve üstü vatandaşların ihtiyaçlarının karşılanması amacıyla oluşturulan "Vefa Sosyal Destek" grupları örnek alınabilir. Ancak bu tür 
çalışmaların pandemi sürecinden bağımsız olarak sonraki yıllarda da çeşitlendirilerek sürdürülmesi önerilmektedir. Örneğin; sivil toplum kuruluşlarının katılımıyla belirli bölgelerde oluşturulacak kuşaklararası dayanışma ağları aracılığıyla, belirli dönemlerde genç ve yaşlı nüfusun bir araya gelmesi sağlanabilir. Ek olarak bu tür ağlar içinde her genç bir yaşlı ile eşleştirilebilir ve gündelik hayatın akışı içinde de ilişkiler kurulması sağlanabilir. Katılımcıların üçte ikisinin yaşlı bir birey ile bir araya gelme sıklı̆̆ının yılda/ayda bir ya da birkaç kez olduğu göz önüne alındığında, bu tür çalışmaların önemi daha iyi anlaşılmaktadır. Ayrıca kuşaklararası mentörlük uygulaması gibi farklı çalışmalar da gerçekleştirilebilir. Bu tür uygulamalarla yaşlı nüfusun bilgi ve tecrübesinin genç nüfusa aktarılması sağlanabileceği gibi; genç nüfusun da başta dijitalleşme, teknoloji, uzay ve çevre gibi konulardaki güncel ve interaktif gelişmeleri yaşlı nüfusa aktarması sağlanabilir. Genç nüfusun en yoğun, buna karşın yaşlı nüfusun ise en az görünür olduğu eğitim kurumlarında gerçekleştirilecek çalışmalarla yaşlı nüfus eğitim süreçlerine dâhil edilebilir. İlköğretim yıllarından itibaren eğitim müfredatına kuşaklararası okuryazarlık, gerontoloji ve yaşam boyu gelişim gibi derslerin eklenmesi, genç nüfusun yaşlı nüfusu daha yakından tanımasına ve anlamasına olanak sağlayabilir. Sonuç olarak bu tür çalışmaların yaşlı ayrımcılığına yönelik olumsuz tutumların engellenmesine ya da minimize edilmesine, aktif/başarılı yaşlanmanın sağlanmasına ve kuşaklararası ilişkilerin ve dayanışmanın geliştirilmesine katkı sağlayacağı öngörülmektedir.

\section{Etik Bilgiler}

Bu araştırmanın etik açıdan uygun olduğuna dair karar Recep Tayyip Erdoğan Üniversitesi Sosyal ve Beşerî Bilimler Etik Kurulunun 10.11.2020 tarih ve 2020/130 sayılı toplantısında alınmıştır. 


\section{Young People's Attitude Toward Ageism In Light of Certain Sociodemographic Variables: The Case of Manisa}

Bekir Güzel*

\section{Introduction}

According to United Nations data, there are 727 million people aged 65 and over worldwide in 2020. It is estimated that this number will more than double to reach over 1.5 billion in 2050. This figure indicates the need for studies to be conducted with the elderly. Indeed, negative points of view, pejorative statements, and disparaging portrayals of elderly people are frequently featured in local, national, and social media. These negative portrayals of the elderly clandestinely reinforce ageist attitudes. The main purpose of this study is to gauge young people's attitudes toward ageism in the sample of Manisa province. Using convenience sampling method, we selected 601 participants to take part in the sample group. The Ageism Attitude Scale (AAS) developed by Vefikuluçay Yılmaz and Terzioğlu (2011), we collected data between November 14, 2020 and March 04, 2021.

After obtaining the necessary permissions to use the scale in the study, the socio-demographic form and scale that had been devised were transferred to Google Forms. This research link was shared on various social media platforms (i.e., Facebook, Twitter, and Instagram) frequented by the young population of Manisa. After a while, however, we understood that we would not be able to reach the desired number of participants. Consequently, the representatives of NGOs, youth centers, and the youth branches of political parties operating in Manisa were contacted and asked to share the research link with their members and stakeholders.

Before analyzing participants' responses to the scale, we created box plots and investigated whether any extreme values existed in the data set. We found four extreme values in the data

* Asst. Prof., Recep Tayyip Erdoğan University, Faculty of Health Sciences, Department of Social Work, bekir.guzel@erdogan. edu.tr, ORCID: 0000-0002-0795-0768. 
set and removed them. Accordingly, the scale was analyzed using data from 597 participants. We conducted an independent sample t-test to compare scores by gender, marital status, and the presence of an elderly family member. An ANOVA test was used to compare age groups, place of residence, employment, monthly income, family type, frequency of interaction with an elderly person, and preference of living in the same house as an elderly individual. Participants scored $36.27 \pm 4.21$ for restricting the lives of elderly individuals, $31.99 \pm 4.32$ for positive ageism, $16.80 \pm 3.43$ for negative ageism. Their total mean scores on the AAS, however, were $85.06 \pm 8.49$.

Participant' scores reveal them to have a positive attitude toward restricting the lives of elderly individuals, a positive attitude toward positive ageism, a positive attitude toward negative ageism, and a positive attitude toward ageism in general. The results, therefore, indicate that a traditional, patriarchal, and altruistic social structure prevails among the young people participating in our study.

It is therefore necessary to create, support, and promulgate intergenerational-living practices in society to achieve genuine social integration, social balance, and harmony. A functional mechanism can be devised and implemented between young and elderly populations with intergenerational solidarity networks or support groups. In addition, intergenerational mentoring and other such activities can be facilitated. These activities should offer elderly individuals an opportunity to impart their knowledge and experience on young people while simultaneously allowing young people to keep elderly people abreast of current and interactive developments in such areas as digitalization, technology, space, and the environment. The elderly population can also be included in education processes through future studies carried out in educational institutions where young people abound and where elderly people make up a very small minority of the population. Such studies will not only contribute to the prevention and/or minimization of ageist attitudes, but also improve active/successful aging, relations between age groups, and intergenerational solidarity.

\section{Kaynakça/References}

- $\quad$ Achenbaum, W. A. (2015). A history of ageism since 1969. Generations, 39(3), 10-16.

- $\quad$ Adıbelli, D., Türkoğlu, N. ve Kılıç, D.(2013). Öğrenci hemşirelerin yaşlılığa ilişkin görüşleri ve yaşlılara karşı tutumları. Dokuz Eylül Üniversitesi Hemşirelik Yüksekokulu Elektronik Dergisi, 6(1), 2-8.

- $\quad$ Ayaz Alkaya, S. ve Birimoğlu Okuyan, C. (2017). Hemşirelik öğrencilerinin yaşlı bireye yönelik tutumları. Hacettepe Üniversitesi Hemşirelik Fakültesi Dergisi, 4(1), 43-52.

- Altay, B. ve Aydın, T. (2015). Hemşirelik öğrencilerinin yaşlı ayrımcllığına ilişkin tutumlarının değerlendirilmesi. Koç Üniversitesi Hemşirelikte Eğitim ve Araştırma Dergisi (HEAD), 12(1), 11-18.

- $\quad$ Altun, A. ve Demirel, B. (2020). Üniversite öğrencilerinin yaşlı ayrımcllığıyla ilgili tutumları: Keskin MYO örneği. Manas Sosyal Araştırmalar Dergisi, 9(1), 423-434.

- $\quad$ Ansell, N. (2005) Children, youth and development, Routledge.

- $\quad$ Ayoğlu, F. N., Kulakçı, H., Ayyıldız, T. K., Aslan, G. K.ve Veren, F. (2014). Attitudes of Turkish nursing and medical students toward elderly people. Journal of Transcultural Nursing, 25(3), 241-248. 
- Başaran, Ö. (2018). Süleyman Demirel Üniversitesi son sınıf lisans öğrencilerinin yaşlı ayrımcılığına ilişkin tutumları ve etkileyen etmenler. [Yayınlanmamış tıpta uzmanlık tezi].. Süleyman Demirel Üniversitesi.

- Başkurt, İ. (2002). Eğitimde çocuk ve ‘öteki’nin kimliği problemi. İstanbul Üniversitesi İlahiyat Fakültesi Dergisi, o(5), 113-141.

- Baysal, E., Sarı, D., Taşkıran, N., Acar, E. ve Çevik Akyıl, R. (2019). Hemşirelik öğrencilerinin yaşlı bireylere yönelik tutumları ve empatik yaklaşım becerileri. Süleyman Demirel Üniversitesi Sağlık Bilimleri Dergisi, 10(2), 80-87.

- Birleşmiş Milletler (2020). World population ageing 2020 highlights, United Nations Department of Economic and Social Affairs Population Division, 06.04.2021 tarihinde https://www.un.org/ development/desa/pd/sites/www.un.org.development.desa.pd/files/undesa_pd-2020_world_ population_ageing_highlights.pdf adresinden erişildi.

- Birleşmiş Milletler (2015). Population Facts: Youth population trends and sustainable development, 09.04.2021 tarihinde https://www.un.org/esa/socdev/documents/youth/fact-sheets/YouthPOP.pdf adresinden erişildi.

- Bond, J. ve Cabrero, G. R. (2007). Health and dependency in later life. Bond, J. Peace, S. Dittmann-Kohli, F. ve Westerhof, G. (Ed.), Ageing in society: European perspectives on gerontology (s. 113-141.) içinde. Sage Publication.

- $\quad$ Boz, H., Gökçe, N., Kıral, A. Ö., Mutlu, E., Selvi, N., Ünlü, D. ve Yılmaz, G. (2017). Sağlık Bilimleri Fakültesi ve İktisadi ve İdari Bilimler Fakültesi öğrencilerinin yaşlı ayrımcılığına ilişkin tutumları. Sağlık Akademisi Kastamonu, 2(1), 1-23.

- $\quad$ Butler, R. N. (1980). Ageism: A foreword. Journal of Social Issues, 36(2), 8-11.

- Buz, S. (2015). Yaşlı bireylere yönelik yaş ayrımcılığı. Elektronik Sosyal Bilimler Dergisi, 14 (53), 268-278.

- Büyüköztürk, Ş. (2019). Sosyal Bilimler için veri analizi el kitabı (25. Baskı). PEGEM Akademi Yayınları.

- $\quad$ Bytheway, B. (2005). Ageism and age categorization. Journal of Social Issues, 61(2), 361-374.

- $\quad$ Canatan, A. (2009) Gençlerin yaşlılarla ilgili düşünceleri. EKEV Akademi Dergisi, 39, 27-28.

- Caner, Ö. C., Gözün, G., Hilwah, A. veGökçek, M. (2013). Yaşlı dostu şehirler: kavramsal çerçeve ve örneklerle değerlendirmeler. Güneş Tıp Kitapevi.

- Ceylan, H., \& Öksüz, M. (2015). Sosyal hizmet lisans öğrencilerinin yaşlı ayrımcılığına ilişkin tutumlarının incelenmesi. Journal of International Social Research, 8(39), 459-466.

- Çağlar, T., (2017). Yaşlı Bakımı: Modeller ve Uygulamalar. Nika Yayınevi.

- Çerik, Ş. (2002). Ailelerin gençlere karşı tutumları ve gençlerin ailelerinin tutumlarını algılayışlarına yönelik üniversite gençliği üzerinde bir araştırma. Ege Akademik Bakış Dergisi, 2(1), 21-24.

- Çilingiroğlu, N. ve Demirel, S. (2004). Yaşlı ayrımcılı̆̆ı. Türk Geriatri Dergisi, 7(4), 225-30.

- Demez, G. (2012). Gençlik ideali: Anti-aging uygulamaları ve değişen yaşlılık algılarının medyada temsili. ETHOS: Felsefe ve Toplumsal Bilimlerde Diyaloglar, 5(1), 94-120.

- Demirel, E. T. (2018). Araştırma tasarımı. Şebnem Arslan (Ed.), Sosyal Bilimlerde Araştırma Yöntemleri içinde. Eğitim Yayınevi.

- $\quad$ Dinçer, Y., Usta, E. ve Bulduk, S. (2016). Üniversite öğrencileri gözüyle yaşlılık nasıl algılanıyor?. Yaşlı Sorunları Araştırma Dergisi, 9(1), 26-38.

- Dünya Sağlık Örgütü (2001). Men, ageing and health: Achieving health across the life span, (No. WHO/ $\mathrm{NMH} / \mathrm{NPH} / 01.2)$.

- $\quad$ Erikson, E. H. (2014). İnsanın 8 Evresi. (Gonca Akkaya, Çev.). Okuyan Us Yayınları.

- Ersoy, E. (2006). Değer farklılaşmalarının sosyolojik boyutu (Malatya Örneği). [Yayınlanmamış Doktora Tezi]. İnönü Üniversitesi. 
- Greenberg, J., Schimel, J. ve Martens, A. (2002). Ageism: denying the face of the future. T. D. Nelson (Ed.), Ageism: Stereotyping and prejudice against older persons (s. 27-48) içinde. The MIT Press.

- $\quad$ Gullette, M. M. (2011). Agewise: Fighting the new ageism in America. University of Chicago Press.

- Güven Ş., Ucakan Muz G. ve Efe Ertürk N. (2012). Üniversite öğrencilerinin yaşlı ayrımcıllğına ilişkin tutumları ve bu tutumların bazı değişkenlerle ilişkisi. Anadolu Hemşirelik ve Sağlık Bilimleri Dergisi, 15(2), 99-105.

- Hughes N.J., Soiza R.L., Chua M., Hoyle G.E., McDonald A., Primrose W.R. ve Seymour D.G. (2008). Medical student attitudes toward older people and willingness to consider a career in geriatric medicine. Journal of the American Geriatrics Society, 56(2): 334-338.

- Iversen, T. N., Larsen, L. ve Solem, P. E. (2009). A conceptual analysis of ageism. Nordic Psychology, 61(3), 4.

- Kaçan, H., Dibekli, E. ve Akkan, K. (2018). Toplumda yaşayan bireylerin yaşlı ayrımcılığı tutum düzeylerinin incelenmesi. Yaşlı Sorunları Araştırma Dergisi, 11(2), 8-15.

- $\quad$ Karaağaç, G., Batık Temel, A. ve Yıldırım, G. (2019). Gençlerin yaşlılığa ilişkin görüş ve düşüncelerinin incelenmesi. Yaşlı Sorunları Araştırma Dergisi, 12(1), 32-41.

- Karadağ, E., İnkaya, B. V. ve Karatay, G. (2012) Hemşirelik öğrencilerinin yaşlı ayrımcılığına ilişkin tutumları. Ege Üniversitesi Hemşirelik Fakültesi Dergisi, 28(2), 31-40.

- $\quad$ Karasar, N. (2020). Bilimsel araştırma yöntemi: kavramlar ilkeler teknikler. Nobel Basımevi.

- $\quad$ Kite, M. E., Stockdale, G. D., Whitley, B. E., Jr., \& Johnson, B. T. (2005). Attitudes toward younger and older adults: an updated meta-analytic review. Journal of Social Issues, 61(2), 241-266.

- $\quad$ Koç, A., Öztaş, D., Uysal, N., Demircan, Z., Erdem, Ö. ve Sarı, E. (2018). Klinik hemşirelerinin yaşlılara ilişkin düşünce ve tutumları. Ankara Medical Journal, 18(4), 500-507.

- $\quad$ Köse, G., Ayhan, H., Taştan, S., İyigün, E., Hatipoğlu, S. ve Açıel, C. H. (2015). Sağlık alanında farklı bölümlerde öğrenim gören öğrencilerin yaşlı ayrımcılı̆̆ına ilişkin tutumlarının belirlenmesi. Gülhane Tip Dergisi, 57(2), 145-151.

- Kurtkapan, H. (2019). Gençlerin yaşlı ayrımcılığına ilişkin tutumları: Nevşehir örneği. Nevşehir Hacl Bektaş Veli Üniversitesi SBE Dergisi, 9(1), 220-237.

- $\quad$ Kutsal, Y. G. (2003). Yaşlanan dünya yaşlanan insan. Geriatri Derneği Yayınları.

- Levy, S. R. ve Macdonald, J. L. (2016). Progress on understanding ageism. Journal of Social Issues, 72(1), 5-25.

- Meisner, B. A. (2020). Are you OK, Boomer? Intensification of ageism and intergenerational tensions on social media amid COVID-19. Leisure Sciences, 1-6.

- $\quad$ Nelson, T. D. (2016). The age of ageism. Journal of Social Issues, 72(1), 191-198.

- Officer, A. ve Fuente-Núñez, V. (2018). A global campaign to combat ageism. Bulletin of the World Health Organization, 96(4), 295.

- $\quad$ Olak, A. ve Tümer, A. (2018). Hemşirelik 1. ve 4. sınıf öğrencilerinin yaşlı ayrımcılığına ilişkin tutumları. OPUS Uluslararası Toplum Araştırmaları Dergisi, 8(14), 53-67.

- $\quad$ Özbek Yazıcı, S., Kalaycı, I., Kaya, E. ve Tekin, A. (2015). Yaşlı bakım programı öğrencilerinin yaşlı ayrımcılığına ilişkin tutumları. Yaşlı Sorunları Araştırma Dergisi, 8(2), 77-87.

- Özmete, E. (2017). Türkiye'de kuşaklararası dayanışmanın değerlendirilmesi. Ankara Üniversitesi Basımevi.

- $\quad$ Palmore, E. (2001). The ageism survey: First findings. The gerontologist, 41(5), 572-575.

- $\quad$ Palmore, E. B., Branch, L. ve Harris, D. K. (Ed.). (2005). Encyclopedia of ageism. Haworth Pastoral Press.

- Pehlivan, O. (2017). Aile tanımı ve ilişkilerinin toplumsal olarak inşası. [Yayınlanmamış doktora tezi]. Hacettepe Üniversitesi. 
- Pehlivan, S. ve Vatansever, N. (2019). Hemşirelerin yaşlıya tutumları ve etkileyen faktörler. Uludağ Üniversitesi Tıp Fakültesi Dergisi, 45(1), 47-53.

- Saramago, J. (2013). Ölüm bir varmış bir yokmuş. (Mehmet Necati Kutlu, Çev.). Kırmızı Kedi Yayınevi.

- Slevin, O. D. (1991). Ageist attitudes among young adults: implications for a caring profession. Journal of advanced nursing, 16(10), 1197-1205.

- Soyuer F., Ünalan, D., Güleser, N. ve Elmalı, F. (2010). Sağlık meslek yüksekokulu öğrencilerinin yaşlı ayrımcılığına ilişkin tutumları ve bu tutumların bazı demografik değişkenlerle ilişkisi. Mersin Üniversitesi Sağlık Bilimleri Dergisi, 3(2), 20-25.

- Söderhamn, O., Lindencrona, C. ve Gustavsson, SM. (2001). Attitudes toward older people among nursing students and registered nurses in Sweden. Nursing Education Today. 21(3): 225-229.

- Stratton, S. J. (2021). Population research: convenience sampling strategies. Prehospital and Disaster Medicine, 36(4), 373-374.

- S Sülüker, K. ve Türkoğlu, N. (2021). Birinci ve ikinci basamakta çalışan hemşirelerin yaşlı ayrımcılığına ilişkin tutumlarının karşılaştırılması. Turkish Journal of Science and Health, 2(1), 166-175.

- Tekin Kaya, N. ve Örsal, ö. (2018). Türkiye’de üniversite öğrencilerinin yaşlı ayrımcılı̆̆ı davranışlarını etkileyen faktörler: sistematik derleme. Akademik Sosyal Araştırmalar Dergisi, 6(67), 540-557.

- Temiz, S. ve Öztürk, M. (2019). Empatinin yaşlı ayrımcllı̆̆ üzerindeki etkisi: gençler üzerine bir araştırma. EKEV Akademi Dergisi, 23(80), 483-498.

- Turğut, F. (2017). Tarihsel süreçte aile kurumunun dönüşümü ve geleceğine yönelik çıkarımlar. Medeniyet ve Toplum Dergisi, 1(1), 93-117.

- Türkiye İstatistik Kurumu (TÜİK). (2020a). İstatistiklerle Yaşlllar (Yayın no.37227). https://data.tuik.gov. tr/Bulten/Index?p=Elderly-Statistics-2020-37227

- Türkiye İstatistik Kurumu (TÜIK). (2020b). İstatistiklerle Gençlik 2019 (Yayın no. 33731). https://tuikweb. tuik.gov.tr/PreHaberBultenleri.do?id=33731

- Türkiye İstatistik Kurumu (TÜiK). (2021). Adrese Dayalı Nüfus Kayıt Sistemi Sonuçları, 2020 (Yayın no. 37210).https://data.tuik.gov.tr/Bulten/Index?p=Adrese-Dayal\%C4\%B1-N\%C3\%BCfus-Kay\%C4\%B1tSistemi-Sonu\%C3\%A7lar\%C4\%B1-2020-37210\&dil=1

- $\quad$ Ucun, Y., Mersin, S. ve Öksüz, E. (2015). Gençlerin yaşlı bireylere karşı tutumu. Journal of International Social Research, 8(37), 1143-1149.

- Ünalan, D., Soyuer, F. ve Elmall, F. (2012). Geriatri merkezi çalışanlarında yaşlı tutumunun değerlendirilmesi. Kafkas Journal of Medical Sciences, 2(3), 115-120.

- Vefikuluçay, D. (2008). Üniversitede öğrenim gören öğrencilerin yaşlı ayrımcılığına ilişkin tutumları. [Yayımlanmış Doktora Tezi]. Hacettepe Üniversitesi.

- Vefikuluçay Yılmaz, D. ve Terzioğlu, F. (2011). Development and psychometric evaluation of ageism attitude scale among the university students. Turkish Journal of Geriatrics, 14(3), 259-268.

- Wyman, M. F., Shiovitz-Ezra, S. ve Bengel, J. (2018). Ageism in the health care system: Providers, patients, and systems. Ayalon, L., Tesch-Römer (Ed.), Contemporary perspectives on ageism (s. 193-212) içinde. Springer.

- Ylldırım Usta, Y., Demir, Y., Yönder, M. ve Yıldız, A. (2012). Nursing students' attitudes toward ageism in Turkey. Archives of Gerontology and Geriatrics, 54(1), 90-93.

- Y Ylmaz, E., ve Özkan, S. (2010). Hemşirelik öğrencilerinin yaşlı ayrımcılığına ilişkin tutumları. Maltepe Üniversitesi Hemşirelik Bilim ve Sanatı Dergisi, 3(2), 35-53.

- Z Zaybak, A., Özdemir, H., Güneş, Ü. ve Baran, L. (2017). Hemşirelik öğrencilerinin yaşlı ayrımcılığına ilişkin tutumlarının incelenmesi. Ege Üniversitesi Hemşirelik Fakültesi Dergisi, 33(1), 21-32. 